\title{
Impact of the 3,6,9-Trioxadecyloxy Group on Desazadesferrithiocin Analogue Iron Clearance and Organ Distribution
}

\author{
Raymond J. Bergeron *, Jan Wiegand, Neelam Bharti, Shailendra Singh, and James R. Rocca \\ Department of Medicinal Chemistry and McKnight Brain Institute, University of Florida, Gainesville, \\ Florida 32610-0485
}

\begin{abstract}
The impact of introducing a 3,6,9-trioxadecyloxyl group at various positions of the desazadesferrithiocin (DADFT) aromatic ring on iron clearance and organ distribution is described. Three DADFT polyethers are evaluated: (S)-4,5-dihydro-2-[2-hydroxy-4-(3,6,9-trioxadecyloxy) phenyl]-4-methyl-4-thiazolecarboxylic acid [(S)-4'-(HO)-DADFT-PE, 3], $(S)-4,5$-dihydro-2-[2hydroxy-5-(3,6,9-trioxadecyloxy)phenyl]-4-methyl-4-thiazolecarboxylic acid [(S)-5'-(HO)DADFT-PE, 6], and (S)-4,5-dihydro-2-[2-hydroxy-3-(3,6,9-trioxadecyloxy)phenyl]-4-methyl-4thiazolecarboxylic acid [(S)-3'-(HO)-DADFT-PE, 9]. The iron-clearing efficiency (ICE) in rodents and primates is shown to be very sensitive to which positional isomer is evaluated, as is the organ distribution in rodents. The polyethers had uniformly higher ICE than their corresponding parent ligands in rodents, consistent with in vivo ligand-serum albumin binding studies. Ligand $\mathbf{9}$ is the most active polyether analogue in rodents and is also very effective in primates, suggesting a higher index of success in humans. In addition, this analogue is also shown to clear more iron in the urine of the primates than many of the other chelators. If this trend were also observed in patients, it would facilitate iron-balance studies in a clinical setting.
\end{abstract}

Humans have evolved a highly efficient iron management system in which we absorb and excrete only about $1 \mathrm{mg}$ of the metal daily; there is no mechanism for the excretion of excess iron. ${ }^{1}$ Whether derived from transfused red blood cells ${ }^{2-4}$ or from increased absorption of dietary iron, 5,6 without effective treatment, body iron progressively increases with deposition in the liver, heart, pancreas, and elsewhere. Iron accumulation eventually produces (i) liver disease that may progress to cirrhosis, ${ }^{7-9}$ (ii) diabetes related both to iron-induced decreases in pancreatic $\beta$-cell secretion and increases in hepatic insulin resistance, ${ }^{10,11}$ and (iii) heart disease, still the leading cause of death in thalassemia major and related forms of transfusional iron overload. $1,12,13$

Although iron comprises 5\% of the earth's crust, living systems have great difficulty in accessing and managing this vital micronutrient. The low solubility of $\mathrm{Fe}(\mathrm{III})$ hydroxide $\left(K_{\mathrm{sp}}=1 \times 10^{-39}\right),{ }^{14}$ the predominant form of the metal in the biosphere, has led to the development of sophisticated iron storage and transport systems in nature. Microorganisms utilize low molecular weight, virtually ferric ion-specific, ligands, siderophores; ${ }^{15,16}$ higher eukaryotes tend to employ proteins to transport and store iron (e.g., transferrin and ferritin, respectively). ${ }^{17-19}$ In humans, nontransferrin-bound plasma iron, a heterogeneous pool of iron

*Corresponding Author: Raymond J. Bergeron, Ph.D., Box 100485 JHMHSC, Department of Medicinal Chemistry, University of Florida, Gainesville, Florida 32610-0485, Phone (352) 846-1956, Fax (352) 392-8406, E-mail: rayb@ufl.edu. 
in the circulation that is not bound to the physiological iron transporter, transferrin, seems to be a principal source of iron-mediated organ damage.

The toxicity associated with excess iron, whether a systemic or a focal problem, derives from its interaction with reactive oxygen species, for instance, endogenous hydrogen peroxide $\left(\mathrm{H}_{2} \mathrm{O}_{2}\right){ }^{20-23}$ In the presence of $\mathrm{Fe}(\mathrm{II}), \mathrm{H}_{2} \mathrm{O}_{2}$ is reduced to the hydroxyl radical (HO'), a very reactive species, and $\mathrm{HO}^{-}$, a process known as the Fenton reaction. The $\mathrm{Fe}(\mathrm{III})$ liberated can be reduced back to $\mathrm{Fe}$ (II) via a variety of biological reductants (e.g., ascorbate), a problematic cycle. The hydroxyl radical reacts very quickly with a variety of cellular constituents and can initiate free radicals and radical-mediated chain processes that damage DNA and membranes, as well as produce carcinogens. ${ }^{21,24,25}$ The solution to the problem is to remove excess unmanaged iron. 26

In the majority of patients with thalassemia major or other transfusion-dependent refractory anemias, the severity of the anemia precludes phlebotomy therapy as a means of removing toxic accumulations of iron. Treatment with a chelating agent capable of sequestering iron and permitting its excretion from the body is then the only therapeutic approach available. The iron-chelating agents now in use or under clinical evaluation 27 include desferrioxamine $B$ mesylate (DFO), 1,2-dimethyl-3-hydroxypyridin-4-one (deferiprone, L1), 4-[3,5-bis(2hydroxyphenyl)-1,2,4-triazol-1-yl]benzoic acid (deferasirox, ICL670A), and the desferrithiocin (DFT) analogue, (S)-2-(2,4-dihydroxyphenyl)-4,5-dihydro-4-methyl-4thiazolecarboxylic acid [deferitrin, $(S)-4^{\prime}-(\mathrm{HO})$-DADFT, 1; Table 1].

Subcutaneous (sc) infusion of desferrioxamine B (DFO), a hexacoordinate hydroxamate iron chelator produced by Streptomyces pilosus, ${ }^{28}$ is still regarded as a credible treatment for handling transfusional iron overload. ${ }^{2,29}$ DFO is not orally active, and when administered sc, has a very short half-life in the body and must therefore be given by continuous infusion over long periods of time. ${ }^{2,30}$ For these reasons, patient compliance is a serious problem. ${ }^{2,29}$ The orally active bidentate chelator, deferiprone, is licensed in Europe and some other countries as second-line therapy to DFO. Unfortunately, although it is orally active, it is less efficient than sc DFO at removing iron. ${ }^{31-34}$ Whereas the orally active tridentate chelator deferasirox has now been approved by the FDA, it did not demonstrate non-inferiority to DFO. Furthermore, it apparently has a somewhat narrow therapeutic window, owing to nephrotoxicity noted in animals during the preclinical toxicity studies. ${ }^{35-37}$ In addition, Novartis has recently (April, 2007) updated the prescribing information for deferasirox: "Cases of acute renal failure, some with a fatal outcome, have been reported following the postmarketing use of Exjade ${ }^{\circledR}$ (desferasirox). Most of the fatalities occurred in patients with multiple co-morbidities and who were in advanced stages of their hematological disorders." 38 Finally, ligand $\mathbf{1}$ is an orally active tridentate DFT analogue now in Phase I/II trials in patients. Although the preclinical toxicity profile of $\mathbf{1}$ was relatively benign, that is, no geno- or reproductive toxicity and only mild nephrotoxicity at high doses, the clinical results remain to be elucidated.

Our previous studies revealed that within a family of desferrithiocin analogues the more lipophilic chelators have better iron-clearing efficiency, that is, the larger the $\log P_{\text {app }}$ value of the compound, the better the iron-clearing efficiency (ICE). $39,40,41$ There also exists a second, albeit somewhat disturbing relationship: in all sets of ligands, the more lipophilic chelator is always the more toxic. ${ }^{39}$ A previous investigation focused on the design of ligands that balance the lipophilicity/toxicity relationship while iron-clearing efficiency is maintained. The study began with the observation that $(S)$-4,5-dihydro-2-(2-hydroxy-4-methoxyphenyl)-4methyl-4-thiazolecarboxylic acid [(S)-4'-( $\left.\mathrm{CH}_{3} \mathrm{O}\right)$-DADFT, 2], a 4'-methyl-ether, had excellent iron-clearing efficiency in both rodents and primates; however, it was unacceptably toxic. ${ }^{39}$, 40 Nevertheless, this established that alkylation of the 4'-(HO) functionality of $(S)-4$ '-(HO)DADFT (1) was compatible with iron clearing function. On the basis of these observations, a 
less lipophilic, more water-soluble ligand than 2 was assembled, the polyether $(S)-4,5$ dihydro-2-[2-hydroxy-4-(3,6,9-trioxadecyloxy)phenyl]-4-methyl-4-thiazolecarboxylic acid $\left[(S)-4^{\prime}-(\mathrm{HO})\right.$-DADFT-PE, 3$] .{ }^{39}$

When $\mathbf{1}$ was 4'-methoxylated to provide 2, the ICE in a rodent model after oral (po) administration increased substantially from $1.1 \pm 0.8 \%$ to $6.6 \pm 2.8 \%(p<0.02) .{ }^{41}$ The polyether (3), in which a 3,6,9-trioxadecyl group was fixed to the 4'-(HO) of $\mathbf{1}$, also performed well, with an ICE of $5.5 \pm 1.9 \%$ when administered po ( $p<0.003$ vs 1$) .39$ The efficiency of

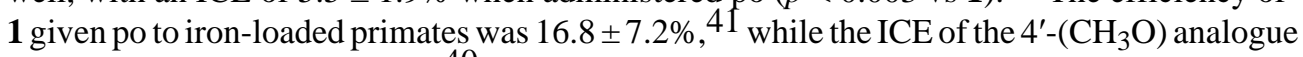
(2) given po was $24.4 \pm 10.8 \% .40$ The corresponding polyether (3) given po performed very well in primates with an efficiency of $25.4 \pm 7.4 \% .39$

Earlier studies carried out in rodents clearly demonstrated the polyether $(S)-4^{\prime}$-(HO)-DADFTPE (3) to be less nephrotoxic than the corresponding $(S)-4^{\prime}-\left(\mathrm{CH}_{3} \mathrm{O}\right)$-DADFT analogue (2) or the parent drug $(S)-4^{\prime}-(\mathrm{HO})$-DADFT $(\mathbf{1}) .{ }^{39}$ In an attempt to understand this difference in toxicity, the tissue levels of $\mathbf{3}$ and $\mathbf{1}$ in the liver, kidney, pancreas, and heart of rodents given a single sc $300 \mu \mathrm{mol} / \mathrm{kg}$ dose of the chelators were measured 2, 4, 6, and $8 \mathrm{~h}$ after exposure.

39 There were two notable observations. At each time point, the level of the polyether 3 in the liver was much higher than that of the parent drug 1 . In the kidney, the polyether concentration was lower than the parent at $2 \mathrm{~h}$ and similar at later time points. ${ }^{39}$ This seemed consistent with the reduced nephrotoxicity. Furthermore, in an experiment in which $\mathbf{1}$ and $\mathbf{3}$ were given po to the rats twice daily at a dose of $237 \mu \mathrm{mol} / \mathrm{kg} / \mathrm{dose}$ ( $474 \mu \mathrm{mol} / \mathrm{kg} /$ day) for 7 days, ${ }^{39}$ under light microscopy, the proximal tubules of kidneys from the polyether $(3)$ treated rodents were indistinguishable from those of the control animals; the distal tubules presented with occasional vacuolization but were otherwise normal. ${ }^{39}$ However, animals treated with $\mathbf{1}$ showed regional, moderate to severe vacuolization in the proximal tubules, a loss of the brush border, and tubular extrusions toward the lumen; the distal tubules showed moderate to severe vacuolization.

These findings, coupled with the increased ICE of the polyether $\mathbf{3}$ compelled us to pursue further studies on additional polyethers and evaluate drug tissue levels at additional (earlier) time points.

\section{Results and Discussion Design Concept}

Desferrithiocin, (S)-4,5-dihydro-2-(3-hydroxy-2-pyridinyl)-4-methyl-4-thiazolecarboxylic acid (DFT), is a tridentate siderophore ${ }^{42}$ that forms a stable $2: 1$ complex with $\mathrm{Fe}(\mathrm{III})$; the cumulative formation constant is $4 \times 10^{29} \mathrm{M}^{-1} .43,44$ It performed well when given orally (po) in both the bile duct-cannulated rodent model (ICE, 5.5\% ${ }^{45}$ and in the iron-overloaded Cebus apella primate (ICE, 16\%). ${ }^{46,47}$ Unfortunately, DFT is severely nephrotoxic. ${ }^{47}$ Nevertheless, the outstanding oral activity spurred a structure-activity study to identify an orally active and safe DFT analogue. Our initial goal was to define the minimal structural platform compatible with iron clearance on po administration. 47,45 This was followed by a series of structureactivity studies aimed at developing a DFT analogue with good oral iron-clearing activity and an acceptable toxicity profile. ${ }^{39,48}$ The outcome was $(S)-4^{\prime}$-(HO)-DADFT (1), ${ }^{48}$ now in clinical trials. However animal studies suggested that even in this system, the dose limiting toxicity would likely be nephrotoxicity. We next discovered that fixing a polyether to the 4'position leading to $(S)-4^{\prime}$-(HO)-DADFT-PE (3) profoundly reduced nephrotoxicity. ${ }^{39}$ The reduction in proximal tubule damage seemed consistent with the reduced level of 3 in the kidney relative to the parent ligand $\mathbf{1}$ at 2 h. ${ }^{39}$

In the current study, we seek to better understand the role the polyether fragment plays from a positional isomer standpoint; the design strategies are based on comparative issues. Three 
questions are addressed: How does altering the position of the polyether in the aromatic ring affect (1) iron-clearing efficiency in rodents, (2) iron-clearing efficiency in primates, and (3) tissue distribution in rodents? With this information, we will decide how best to conduct possible further and protracted toxicity trials in rodents.

A simple platform, (S)-4,5-dihydro-2-(2-hydroxyphenyl)-4-methyl-thiazolecarboxylic acid (DADFT) is evaluated in this study. In each instance, a single substituent, hydroxy, methoxy, or 3,6,9-trioxadecyloxy was added to the $3^{\prime}(\mathbf{7 - 9}), 4^{\prime}(\mathbf{1}-\mathbf{3})$ or 5' (4-6) positions of the aromatic ring. In each instance, the iron clearance data is presented in both rodents and primates, along with $\log P_{\text {app }}$ numbers (Tables 1 and 2). Historical data is included. ${ }^{39,40,41,48,49}$ Discussion of organ distribution of the ligands in rodents will be limited to $(S)-4^{\prime}$-(HO)-DADFT (1) and the three trioxadecyloxy compounds $\mathbf{3}, \mathbf{6}$ and $\mathbf{9}$ (Figure 4). Organ distribution data for the nonpolyethers 2,4 and 5 can be found in a previous publication. ${ }^{41}$

\section{Synthesis}

The syntheses of $(S)$-4,5-dihydro-2-[2-hydroxy-5-(3,6,9-trioxadecyloxy)phenyl]-4-methyl-4thiazolecarboxylic acid [(S)-5'-(HO)-DADFT-PE, 6] and (S)-4,5-dihydro-2-[2-hydroxy-3(3,6,9-trioxadecyloxy)phenyl]-4-methyl-4-thiazolecarboxylic acid [(S)-3'-(HO)-DADFT-PE (9)] were achieved by first converting (S)-2-(2,5-dihydroxyphenyl)-4,5-dihydro-4-methyl-4thiazolecarboxylic acid [(S)-5'-(HO)-DADFT, 4] and (S)-2-(2,3-dihydroxyphenyl)-4,5dihydro-4-methyl-4-thiazolecarboxylic acid [(S)-3'-(HO)-DADFT, 7] to their isopropyl ester 10 and ethyl ester 11, respectively (Scheme 1). (S)-5'-(HO)-DADFT (4) was converted to its isopropyl ester 10 in quantitative yield by alkylation with 2-iodopropane (1.8 equiv) in DMF in the presence of $N, N$-diisopropylethylamine (1.8 equiv). The ethyl ester of $(S)$-3'-(HO)DADFT, 11, was accessed by alkylation of 7 with iodoethane (1.8 equiv) and $N, N$ diisopropylethylamine (1.8 equiv) in DMF. Compounds $\mathbf{1 0}$ and $\mathbf{1 1}$ were then alkylated at the 5'-hydroxyl and 3'-hydroxyl using an equimolar amount of tri(ethylene glycol) monomethyl ether under Mitsunobu conditions [diisopropyl azodicarboxylate (1.19 equiv) and triphenylphosphine (1.23 equiv) in THF], providing ( $S$ )-5'-(HO)-DADFT-PE-iPrE (12) and $(S)-3$ '-(HO)-DADFT-PE-EE (13) in 52 and 25\% yield, respectively. Hydrolysis of isopropyl and ethyl ester with $50 \% \mathrm{NaOH}$ in methanol followed by acidification with $2 \mathrm{~N} \mathrm{HCl}$ furnished $(S)-5$ '-(HO)-DADFT-PE $(6,97 \%)$ and $(S)-3$ '-(HO)-DADFT-PE (9) in $60 \%$ yield.

\section{Structural Assignment}

In order to demonstrate that the polyether chain of 9 was indeed fixed to the $3^{\prime}$-position and not to its 2'-hydroxyl, proton Nuclear Overhauser Effect (NOE) difference spectra were acquired and the results are shown in Figure 1. Low-power saturation of the resonance at 4.28 $\mathrm{ppm}$, assigned to the protons of the polyether's methylene (g) most proximate to the aromatic residue, enhanced the signal for the adjacent methylene (e) at $3.94 \mathrm{ppm}$ by $6 \%$, while a single aromatic signal at $7.30 \mathrm{ppm}$ (i) also showed a significant enhancement of $11 \%$. These observations are consistent with the structure for $\mathbf{9}$ as drawn.

Proton NOE difference spectroscopy was also used to verify that alkylation of the polyether chain occurred at the 5'-position in $\mathbf{1 2}$ and not at the more sterically hindered 2'-hydroxyl; these results are shown in Figure 2. Irradiation of the signal at $4.10 \mathrm{ppm}$, assigned to methylene (h) in the polyether chain, enhanced the neighboring methylene (f) resonance at $3.84 \mathrm{ppm}$ by $6 \%$, and two aromatic signals at $6.94 \mathrm{ppm}(\mathrm{j})$ and $7.01 \mathrm{ppm}(\mathrm{k})$ showed significant enhancements of $13 \%$ and $7 \%$ respectively. These enhancements indicate that the structure for $\mathbf{1 2}$ is correct as shown and thus the resulting hydrolysis product is indeed $\mathbf{6}$. 


\section{Chelator-Induced Iron Clearance in Non-Iron-Overloaded Rodents}

We previously demonstrated that in the $(S)-4^{\prime}-(\mathrm{HO})$-DADFT series, $(S)-4^{\prime}-(\mathrm{HO})$-DADFT (1), $(S)-4^{\prime}-\left(\mathrm{CH}_{3} \mathrm{O}\right)$-DADFT (2) and $(S)-4^{\prime}-(\mathrm{HO})$-DADFT-PE (3), both the methoxy ligand (2; ICE $6.6 \pm 2.8 \%)$ and the polyether $(3$; ICE $5.5 \pm 1.9 \%)$ were more efficient iron chelators than the parent ligand $\mathbf{1}$; ICE $1.1 \pm 0.8 \%$ ( $p<0.02$ vs 2 and $p<0.003$ vs 3 ), respectively (Table 1). ${ }^{39}$ Recall that iron clearing efficiency (ICE) is defined as (net iron excretion)/(total iron-binding capacity of the chelator), expressed as a percent. The relative ICE values of compounds $\mathbf{1}$ and 2 were in keeping with their $\log P_{\text {app }}$ values: the more lipophilic, the larger $\log P_{\text {app }}$, the more efficient the chelator. This was not the case with the polyether analogue 3 ; it was much more active than its $\log P_{\text {app }}$ would have predicted. However, The ICE trend was in keeping with the biliary ferrokinetics (Figure 3 ) and liver concentration of the chelators, e.g., $\mathbf{3}>\mathbf{1}$ (Figure 4).

With the (S)-5'-(HO)-DADFT series (Table 1), (S)-5'-(HO)-DADFT (4), $(S)$-4,5-dihydro-2(2-hydroxy-5-methoxyphenyl)-4-methyl-4-thiazolecarboxylic acid [ $(\mathrm{S})-5^{\prime}-\left(\mathrm{CH}_{3} \mathrm{O}\right)$-DADFT, 5] and $(S)-5^{\prime}-(\mathrm{HO})$-DADFT-PE (6), both the methoxy analogue 5 (ICE $6.3 \pm 1.2 \%$ ) and the polyether $\mathbf{6}$ (ICE $8.0 \pm 1.8 \%$ ) were more efficient iron chelators than the parent ligand 4 (ICE $1.0 \pm 0.9 \%, p<0.001$ vs 5 and $p<0.005$ vs $\mathbf{6}$, respectively). Again, the relative ICEs of 4 versus 5 were in keeping with the $\log P_{\text {app }}$ and liver concentrations. ${ }^{41}$ Although liver concentration (Figure 4) was a good indicator of the ICE of polyether 6 , relative to $4,41 \mathrm{log}$ $P_{\text {app }}$ was not. It is notable that in both the $(S)-5^{\prime}-(\mathrm{HO})$-DADFT and $(S)-4^{\prime}-(\mathrm{HO})$-DADFT series, the corresponding $\mathrm{HO}-, \mathrm{CH}_{3} \mathrm{O}$ - and polyether ligands have similar ICE values and similar iron clearance distribution in the urine and bile (Table 1).

The ICEs of the (S)-3'-(HO)-DADFT set of compounds 7-9 are very different than the 4'-(HO) and $5^{\prime}-(\mathrm{HO})$ series. The ligands are, as a family, more efficient at clearing iron (Table 1). Again, although the relative iron clearing efficiencies are predicted by the $\log P_{\text {app }}$ values for the $3^{\prime}$ $(\mathrm{HO})$ and $3^{\prime}-\left(\mathrm{CH}_{3} \mathrm{O}\right)$ compounds, the ICE for the $3^{\prime}$-polyether $(9)$ is not. What is most relevant in this instance is the profound difference in ICE between the 3'-polyether (9) and the 4'polyether (3); the $3^{\prime}$-ligand (9) is nearly $200 \%$ more effective (10.6 $\pm 4.4 \%$ vs $5.5 \pm 1.9 \%, p<$ $0.05)$. The ICE of 9 is also greater than that of $6,(10.6 \pm 4.4 \%$ vs $8.0 \pm 1.8 \%$, respectively), but the increase is slightly less than significant $(p=0.06)$. The modes of iron excretion, urine versus bile, are similar.

The biliary ferrokinetics of the parent $\mathbf{1}$ and the three polyethers $\mathbf{3 , 6}$ and $\mathbf{9}$ (Figure 3) show that the iron clearance $(\mu \mathrm{g} / \mathrm{kg})$ of ligand 1 peaks at $3 \mathrm{~h}$ post drug and never exceeds $68 \mu \mathrm{g} / \mathrm{kg}$. The iron excretion induced by the $4^{\prime}$ - and 5'-polyethers $(\mathbf{3}$ and $\mathbf{6})$ also peak at $3 \mathrm{~h}$, but at much higher levels, 183 and $388 \mu \mathrm{g} / \mathrm{kg}$, respectively ( $p<0.001$ for $\mathbf{1}$ vs $\mathbf{3}$ or $\mathbf{6}$ ). The biliary iron content of 3'-polyether 9 treated animals is greatest at $6 \mathrm{~h}, 287 \mu \mathrm{g} / \mathrm{kg}$. In addition, while the biliary iron clearance for $\mathbf{1 , 3}$ and $\mathbf{6}$ have returned to baseline levels by $15 \mathrm{~h}$, the $3^{\prime}$-polyether (9) remains well above this until $>30 \mathrm{~h}$ (data not shown). The delayed peak in iron excretion and duration of activity of $\mathbf{9}$ are also reflected in the tissue distribution studies (Figure 4), discussed below.

\section{Chelator-Induced Iron Clearance in Iron-Overloaded Cebus apella Primates}

The iron-clearance data for all three sets of ligands are presented (Table 2). In the case of the $(S)-4$ '-(HO)-DADFT series in primates, while the mean ICE values for $(S)$-4'-(HO)-DADFT (1) and $(S)-4$ '- $\left(\mathrm{CH}_{3} \mathrm{O}\right)$-DADFT (2) suggest a correlation with $\log _{\text {app }}$, e.g., the ICE of the more lipophilic analogue $2(24.4 \pm 10.8 \%)^{40}>\mathbf{1}(16.8 \pm 7.2 \%), 48$ the increase is not significant. Although $(S)-4^{\prime}-(\mathrm{HO})-\mathrm{DADFT}-\mathrm{PE}(\mathbf{3})$ is the least lipophilic chelator in the 1-3 series, it is just as efficient (ICE, $25.4 \pm 7.4 \%)^{39}$ as analogue 2 and is slightly more effective than the parent 1 , although the increase was not significant $(p=0.06)$. 
In the case of the (S)-5'-(HO)-DADFT analogues 4-6, the ligands' ICE trend correlates well with $\log P_{\text {app }}$. The ICE of the most lipophilic ligand $\mathbf{5}(18.9 \pm 2.3)$ is more than twice as efficient as the least lipophilic analogue $\mathbf{6}$ (ICE $8.1 \pm 2.8 \%, p<0.001$ ); 5 is also more efficient than chelator 4, ICE $12.6 \pm 3.0 \%(p<0.01) .{ }^{41}$ With the $(S)-3$ '-(HO)-DADFT analogues 7-9, while there are clear differences in $\log P_{\text {app }}$, the ICEs of the three ligands are all within error of each other (Table 2).

A final, comparative note concerning the polyether ligands relates to the biliary versus urinary metal excretion. In the rodent model, the numbers are generally similar, with nearly all of the iron excreted in the bile (Table 1). This is not the case with the primates; a much larger fraction of the iron is found in the urine (Table 2). The most notable cases are (S)-5'-(HO)-DADFT-PE (6) with 56/44 feces/urine ratio and (S)-3'-(HO)-DADFT-PE (9) with 72/28 feces/urine ratio in primates. In rodents, these numbers are $98 / 2$ and $95 / 5$, respectively.

\section{Iron Clearance Performance Ratio in Primates versus Rodents}

The performance ratio (PR), defined as the mean $\mathrm{ICE}_{\text {primates }} / \mathrm{ICE}_{\text {rodents }}$, is noteworthy (Table 3 ). At first glance, it does not seem surprising that the ligands uniformly perform better in the iron-overloaded primates than in the non-iron-overloaded rats (Tables 1 and 2). The mean ICE for the primate group can be compared with the mean ICE of the rodent group (Table 3). Although the standard deviations for the two species are not equivalent for 1-5 and 7-9, this is not a concern since the intervals containing the means do not interact. This is not the case with the 5'-polyether (6), whose ICE is virtually identical in the two species. The largest differences in performance ratios generally unfold with the parent ligands $\mathbf{1 , 4}$, and $\mathbf{7}$. However, the fact that the ratios change so profoundly within sets (i.e., $\mathbf{1}$ vs $\mathbf{2}$ and $3, \mathbf{4}$ vs $\mathbf{5}$ and $\mathbf{6}$, and 7 vs 8 and 9) suggests that the difference in ICE in primates versus rodents is not based entirely on the fact the monkeys are iron-overloaded, while the rodents are not.

\section{The Possible Impact of Ligand-Albumin Binding on ICE}

In an attempt to understand the differences in ICE between the parent ligands $\mathbf{1 , 4}$, and $\mathbf{7}$ and their analogues in the rodent model, we conducted a series of experiments focused on ligandalbumin binding. We elected to focus on the drug that is under clinical trials with Genzyme, $(S)-4$ '-(HO)-DADFT (1). Recall, the corresponding polyether (3) performed significantly better in the rodent (ICE $5.5 \pm 1.9 \%$ vs $1.1 \pm 0.8 \%$ for $\mathbf{3}$ and $\mathbf{1}$, respectively). ${ }^{39} \mathrm{~A}$ series of comparative experiments in rats focused on displacing $(S)$-4'-(HO)-DADFT (1) and $(S)-4^{\prime}$ (HO)-DADFT-PE (3) from serum albumin binding sites were carried out.

Benzoic acid has been well established as a ligand that will displace drugs from both sites in human serum albumin. ${ }^{50} \mathrm{We}$ elected to evaluate the impact of treating bile duct-cannulated rodents with sodium benzoate to displace any chelator potentially bound to Sudlow type I and II albumin binding sites. ${ }^{50}$ Five experiments were carried out (Table 4). Rodents were given (i) sodium benzoate dissolved in distilled water at $250 \mathrm{mg} / \mathrm{kg} / \mathrm{dose}$ sc times six doses, (ii) (S)-4'-(HO)-DADFT (1) po at $300 \mu \mathrm{mol} / \mathrm{kg}$, (iii) 1 given po at $300 \mu \mathrm{mol} / \mathrm{kg}$ plus sodium benzoate $(250 \mathrm{mg} / \mathrm{kg} / \mathrm{dose})$. The sodium benzoate was given $0.5 \mathrm{~h}$ pre 1 and hourly thereafter for five additional doses, (iv) (S)-4'-(HO)-DADFT-PE (3) administered po at $300 \mu \mathrm{mol} / \mathrm{kg}$, or (v) 3 dosed at $300 \mu \mathrm{mol} / \mathrm{kg}$ po plus sodium benzoate $(250 \mathrm{mg} / \mathrm{kg} / \mathrm{dose})$. The sodium benzoate was again given $0.5 \mathrm{~h}$ pre $\mathbf{3}$ and hourly thereafter for five additional doses. The results (Table 4) indicate that the sc administration of sodium benzoate itself does not induce the clearance of any iron. However, when sodium benzoate is administered to the rodents as described above in addition to 1 , there is a 10.9-fold increase in the ICE, from $1.1 \pm 0.8 \%$ to $12.0 \pm 2.6 \%$ ( $p<$ $0.001)$. Under the same conditions, the ICE of (S)-4'-(HO)-DADFT-PE (3) also increases, but by a much smaller magnitude, from $5.5 \pm 1.9 \%$ to $8.8 \pm 2.4 \%(p<0.05)$, a 1.6-fold increase. Lower dosing of sodium benzoate had a lesser effect on increasing the ICE of 1 (data not 
shown). These data are consistent with the idea that the difference in ICE in rodents between parent ligands and the corresponding polyethers may well be dependent on ligand-albumin binding differences. The data may also be consistent with the difference in performance ratios in primates versus rodents, that is, the ligands may uniformly bind less tightly to primate albumin than to rodent albumin. This is currently under investigation along with human ligandalbumin binding.

\section{Chelator Tissue Distribution in Rodents}

Two issues were addressed regarding moving the 3,6,9-trioxadecyloxy (polyether) group around the DADFT aromatic ring - the impact on ICE and the effect on tissue distribution. These assessments represent the first step in identifying which, if any, additional DADFT polyethers should be moved forward into protracted toxicity trials in rodents.

The current study clearly indicates that moving the polyether from the 4'- to the 3'- or 5'position of the aromatic ring of DADFT can have a profound effect on ICE (Tables 1 and 2) and tissue distribution (Figure 4) of the resulting ligands. In the kidney (Figure 4 ) at the $0.5 \mathrm{~h}$ time point, the $5^{\prime}$-polyether $(6)$ achieved the highest concentration $(643 \pm 92 \mathrm{nmol} / \mathrm{g}$ wet weight), followed by the 4 '-polyether $(3 ; 368 \pm 74 \mathrm{nmol} / \mathrm{g}$ wet weight, $p<0.01 \mathrm{vs} \mathbf{6})$ and $3^{\prime}$ polyether $(\mathbf{9} ; 280 \pm 26 \mathrm{nmol} / \mathrm{g}$ wet weight, $p<0.01 \mathrm{vs} \mathbf{6})$. Interestingly, at this time point, the concentration of the $4^{\prime}$-polyether $(3)$ and the parent $(1 ; 361 \pm 56 \mathrm{nmol} / \mathrm{g}$ wet weight $)$ were nearly identical $(p>0.05)$. At $1 \mathrm{~h}$, again the $5^{\prime}$-ligand (6) was most concentrated $(435 \pm 111$ $\mathrm{nmol} / \mathrm{g}$ wet weight), with the 3 '-chelator (9) and 4 '-chelator (3) achieving very similar levels $(259 \pm 35$ and $252 \pm 10 \mathrm{nmol} / \mathrm{g}$ wet weight, respectively). The parent drug 1 was the least concentrated ( $179 \pm 4 \mathrm{nmol} / \mathrm{g}$ wet weight). At $2 \mathrm{~h}$, the relative kidney levels are indeed different. Again, the 5'-ligand (6) was most concentrated (321 $\pm 20 \mathrm{nmol} / \mathrm{g}$ wet weight $\gg \mathbf{9} ; 145 \pm 27$ $\mathrm{nmol} / \mathrm{g}$ wet weight $\gg \mathbf{3} ; 41 \pm 3 \mathrm{nmol} / \mathrm{g}$ wet weight $(p<0.001$ for $\mathbf{6}$ vs 9 or 3 ). At $4 \mathrm{~h}$, the order was now $\mathbf{6}(116 \pm 65 \mathrm{nmol} / \mathrm{g}$ wet weight $) \approx \mathbf{9}(90 \pm 7 \mathrm{nmol} / \mathrm{g}$ wet weight $)>\mathbf{3}(34 \pm 13 \mathrm{nmol} /$ $\mathrm{g}$ wet weight $) \approx \mathbf{1}\left(27 \pm 7 \mathrm{nmol} / \mathrm{g}\right.$ wet weight). Recall, previous studies demonstrated the $4^{\prime}-$ polyether (3) to be much less nephrotoxic than the parent drug $(S)-4^{\prime}-\left(\right.$ HO)-DADFT (1). ${ }^{39}$ This was consistent with the relative tissue levels at the $2 \mathrm{~h}$ time point: the 4 '-polyether concentration 3 was much lower than the parent $1 .{ }^{39}$ However, renal concentration data derived from time points taken earlier than $2 \mathrm{~h}$ are not consistent with the idea that reduced nephrotoxicity of the 4 '-polyether (3) relative to the parent (1) can be explained simply by lower kidney chelator levels.

At $0.5 \mathrm{~h}$, the liver concentrations of the three polyether ligands (Figure 4) follow the same relative order as seen in the kidney, $\boldsymbol{6}(483 \pm 85 \mathrm{nmol} / \mathrm{g}$ wet weight $)>\mathbf{3}(339 \pm 35 \mathrm{nmol} / \mathrm{g}$ wet weight $)>9(242 \pm 38 \mathrm{nmol} / \mathrm{g}$ wet weight $)$. At $1 \mathrm{~h}$ the concentrations of all three polyether analogues are similar in the liver $(\approx 315 \mathrm{nmol} / \mathrm{g}$ wet weight). Interestingly, at $1 \mathrm{~h}$ the concentration of the 3 '-polyether $(9)$ has significantly increased from $242 \pm 38 \mathrm{nmol} / \mathrm{g}$ wet weight to $318 \pm 46 \mathrm{nmol} / \mathrm{g}$ wet weight $(p<0.05)$, while the concentrations of 6 and $\mathbf{3}$ have decreased by $36 \%$ and $6 \%$, respectively. At $2 \mathrm{~h}$ and $4 \mathrm{~h}$, the $3^{\prime}$-ligand $(9)$ is the most concentrated in the liver, followed by the $5^{\prime}$-analogue (6) and $4^{\prime}$-analogue (3). The liver concentration of the parent $\mathbf{1}$ is lower than the polyethers at all time points (Figure 4).

In the heart at $0.5 \mathrm{~h}$ (Figure 4 ) the relative concentration of the polyethers $(6>3>9)$ follows the same trend as in the kidney and liver at the same time point. However, the actual levels are much lower, $<90 \mathrm{nmol} / \mathrm{g}$ wet weight. The order of concentration in the heart remains the same at $1 \mathrm{~h}$ and $2 \mathrm{~h}$. At $4 \mathrm{~h}$, the $5^{\prime}$-ligand $(\mathbf{6})$ is still the most concentrated chelator. Although the parent drug $\mathbf{1}$ is higher than 9 at $0.5 \mathrm{~h}$, it is the least concentrated ligand at all other time points (Figure 4). 
In the pancreas (Figure 4), the relative concentration of the polyethers is $\mathbf{6}>\mathbf{3}>\mathbf{9}$ at all time points. The tissue content of both 3 and 9 increase from $0.5 \mathrm{~h}$ to $1 \mathrm{~h}$ (Figure 4 ). At $2 \mathrm{~h}$, the levels of 3 and $\mathbf{6}$ are similar ( $\approx 30 \mathrm{nmol} / \mathrm{g}$ wet weight), while the concentration of 9 is $16 \mathrm{nmol} /$ $\mathrm{g}$ wet weight. The parent drug (1) is higher in concentration than $\mathbf{3}$ and $\mathbf{9}$ at $0.5 \mathrm{~h}$ and similar at $1 \mathrm{~h}$ (Figure 4). At $2 \mathrm{~h}, \mathbf{1}$ is the least concentrated ligand and is undetectable at $4 \mathrm{~h}$.

The plasma chelator concentration data (Figure 4) are consistent with the idea that the ligands are cleared quickly. At $0.5 \mathrm{~h}$ the plasma ligand levels [6 $(324 \pm 20 \mu \mathrm{M})>\mathbf{3}(194 \pm 60 \mu \mathrm{M})>$ $9(62 \pm 24 \mu \mathrm{M})]$ mirror what is occurring in the liver, kidney, pancreas, and heart. At $1 \mathrm{~h}$, while the order is the same, $\mathbf{6}$ has diminished by $39 \%, \mathbf{3}$ by $28 \%$, and 9 by $26 \%$. At $2 \mathrm{~h}, \mathbf{6}$ is now down by $54 \%, 3$ by $92 \%$, and 9 by $61 \%$. At 4 h, 6 has dropped by $82 \%, 3$ by $97 \%$ and 9 by $79 \%$. The drop in plasma concentration of ligand $\mathbf{3}$ is considerably faster than the disappearance of $\mathbf{6}$ or $\mathbf{9}$. However, $\mathbf{9}$ never achieves plasma levels close to $\mathbf{3}$ and $\mathbf{6}$. The parent drug $\mathbf{1}$ is only higher in concentration than 9 at $0.5 \mathrm{~h}$; it is lower than all other ligands at all other time points (Figure 4). This observation relative to liver concentrations of the chelators suggests an efficient first-pass clearance of $\mathbf{1}$ and $\mathbf{9}$. Because of the excellent ICE of the 3'-polyether (9) and its moderate kidney concentrations, this ligand will be moved forward into preclinical toxicity trials. What is particularly intriguing about this ligand is the fact it performs so well in both the rodents and the primates, suggesting a higher index of success in humans.

\section{Conclusion}

Early studies clearly demonstrated the polyether $(S)-4^{\prime}-(\mathrm{HO})$-DADFT-PE $(3)$ to be profoundly less nephrotoxic in rodents than the corresponding $(S)-4^{\prime}-\left(\mathrm{CH}_{3} \mathrm{O}\right)$-DADFT $(2)$ or the parent drug (S)-4'-(HO)-DADFT (1). ${ }^{39}$ The polyether $\mathbf{3}$ was also shown to have excellent ironclearing efficiency in primates. The histopathology of kidneys of rats treated with $(S)-4$ '-(HO)DADFT-PE (3) presented with significantly fewer structural alterations in the proximal tubules than did tissues taken from rodents exposed to the parent ligand 1. ${ }^{39}$ Initial kidney tissue level measurements taken at $2 \mathrm{~h}$ from animals treated with the 4 '-polyether (3) seemed consistent with the histopathology; there was less polyether in the kidney than the parent drug and less nephrotoxicity. ${ }^{39}$ The ICE in both rodents and primates and the absence of toxicity seen with the 4-polyether (3) compelled us to investigate the impact of fixing the 3,6,9-polyether chain to the aromatic ring of DADFT at positions other than the 4'-carbon had on ICE and ligand tissue distribution. Two systems were chosen, $(S)$-3'-(HO)-DADFT-PE $(9)$ and $(S)$-5'-(HO)DADFT-PE (6) (Tables 1 and 2).

The key step in the assembly of the two ligands (Scheme 1) involved alkylation of either 2,5dihydroxy isopropyl ester (10) or the 2,3-dihydroxy ethyl ester (11) with tri(ethylene glycol) monomethyl ether under Mitsunobu conditions. This alkylation was followed by ester hydrolysis. Mitsunobu alkylation was highly specific for the $5^{\prime}$ or the $3^{\prime}$ and did not involve the $2^{\prime}-(\mathrm{HO})$, probably for steric reasons. The regioselectivity of the reaction was consistent with Nuclear Overhauser Effect difference spectra (Figures 1 and 2) of both polyethers 9 and 12.

While $\log P_{\text {app }}$ was a predictor of ICE in the rodents in the case of the methoxylated analogues versus their corresponding parents ( 1 vs $\mathbf{2}),\left(\mathbf{4}\right.$ vs $\mathbf{5}$ ), and ( $\mathbf{7}$ vs $\mathbf{8}$ ) and with the $5^{\prime}$-substitued ligands 4-6 in primates, it was not a useful tool for parent versus polyether. In each set of compounds in rodents, the ICE of the polyether was significantly greater than that of the parent ligand $(\mathbf{1}$ vs $\mathbf{3}, 500 \%, p<0.003 ; \mathbf{4}$ vs 6, 800\%, $p<0.005$ and $\mathbf{7}$ vs $\mathbf{9}, 230 \%, p<0.05$; Table 1 ). This suggested that there may well be additional parameters beyond ligand-metal access that control ICE: efficiency of the metal complex transport through various organic anion transports, such as cMOAT, $\log P_{\text {app }}$ of the metal complex themselves, and ligand-albumin binding. 
The ICE differences between parent and polyether, for example, $(S)-4$ '-(HO)-DADFT (1) and $(S)-4$ '-(HO)-DADFT-PE (3), in rodents was shown to parallel ligand-albumin binding differences (Table 3). Rodents were given sodium benzoate, a compound known to displace ligands from Sudlow type I and II albumin binding sites, along with either $\mathbf{1}$ or $\mathbf{3}$. The sc administration of sodium benzoate increased the ICE of 1 by 10.9 -fold $(p<0.001)$. The ICE of animals given ligand $\mathbf{3}$ and sodium benzoate also increased, but only by 1.6 -fold $(p<0.05)$. This may ultimately explain, at least in part, the difference in ligand ICE in primates versus rodents. The chelators may uniformly bind more weakly to primate albumin.

In the primates, the differences in ligand ICE were not as profound and were generally within experimental error (Table 2), except for 4 versus $\mathbf{6}$, in which the parent's ICE $(12.6 \pm 3.0 \%)$ was greater than that of the corresponding polyether $6(8.1 \pm 2.8 \%, p<0.05)$.

The effect of altering the position of the polyether on ligand-tissue concentrations is significant (Figure 4). The trend in all tissue concentrations except the liver is generally $(S)-5^{\prime}-(\mathrm{HO})$ DADFT-PE (6) > $(S)$-4'-(HO)-DADFT-PE (3) > $(S)$-3'-(HO)-DADFT-PE (9). In the liver at $0.5 \mathrm{~h}$, the concentrations are also $\mathbf{6}>\mathbf{3}>\mathbf{9}>\mathbf{1}$, and at $1 \mathrm{~h}, \mathbf{6} \approx \mathbf{3} \approx \mathbf{9} \gg \mathbf{1}$. However, beyond that time point, 9 achieves and remains at the highest concentration. The most confounding piece of data is associated with the kidney ligand concentration of (S)-4'-(HO)-DADFT-PE (3) at time points earlier than $2 \mathrm{~h}$. Previous studies clearly demonstrated the $4^{\prime}$-polyether (3) to be much less nephrotoxic than the parent drug $(S)-4^{\prime}-(\mathrm{HO})$-DADFT (1). ${ }^{39}$ This was consistent with the renal tissue levels $(\mathbf{1}>\mathbf{3})$ at the $2 \mathrm{~h}$ time point. ${ }^{39}$ However, in the current study $\mathbf{1}$ and $\mathbf{3}$ were found to have similar concentrations at $0.5 \mathrm{~h}$; ligand $\mathbf{3}$ is actually slightly higher than 1 at $1 \mathrm{~h}$. Thus it seems that the reduced toxicity of the polyether 3 relative to the parent $\mathbf{1}$ cannot be explained simply by kidney chelator concentrations.

Finally, the performance ratios ( $\mathrm{ICE}_{\text {primates }} / \mathrm{ICE}_{\text {rodents }}$ ) of ligands $\mathbf{3 ,} \mathbf{6}$ and $\mathbf{9}$ are all $<4.6$, suggesting comparable iron clearance between the two species. Although ligand $\mathbf{6}$ has virtually identical ICEs in the primates and rodents $(\mathrm{PR}=1.0$ ), it is the least efficient (ICE $8.1 \pm 2.8 \%$ ) of the three polyethers in primates and will not be pursed further. While $3^{\prime}-\left(\mathrm{CH}_{3} \mathrm{O}\right)$-DADFT (8) is the most effective chelator in rodents $(12.4 \pm 3.5 \%)$ and performs well in primates (22.5 $\pm 7.1 \%$ ), it is expected to have a toxicity profile (nephrotoxicity) similar to that of the $4^{\prime}-$ and $5^{\prime}-\left(\mathrm{CH}_{3} \mathrm{O}\right)$-DADFT ligands $\mathbf{2}^{39}$ and $\mathbf{5}, 41$ respectively and will not be moved forward. The (S)-3'-(HO)-DADFT-PE (9) works well in both primates $(24.5 \pm 7.6 \%)$ and rats $(10.6 \pm 4.4 \%)$, PR 2.3, suggesting a higher index of success in a third species, humans. In addition, if the relatively large fraction of the iron excreted in the urine of the monkeys were also found in the urine of patients, performance of iron-balance studies would be facilitated. This chelator will be moved forward into protracted preclinical toxicological assessments in rodents.

\section{Experimental Section}

C. apella monkeys were obtained from World Wide Primates (Miami, FL). Male SpragueDawley rats were procured from Harlan Sprague-Dawley (Indianapolis, IN). Cremophor RH-40 was acquired from BASF (Parsippany, NJ). Ultrapure salts were purchased from Johnson Matthey Electronics (Royston, U.K.). All hematological and biochemical studies 47 were performed by Antech Diagnostics (Tampa, FL). Atomic absorption (AA) measurements were made on a Perkin-Elmer model 5100 PC (Norwalk, CT). Histopathological analysis was carried out by Florida Vet Path (Bushnell, FL).

\section{Cannulation of Bile Duct in Non-Iron-Overloaded Rats}

The cannulation has been described previously. ${ }^{46,47}$ Bile samples were collected from male Sprague-Dawley rats (400-450 g) at 3-h intervals for up to $48 \mathrm{~h}$. The urine sample(s) was taken at $24 \mathrm{~h}$ intervals. Sample collection and handling are as previously described. 46,47 


\section{Iron Loading of $\boldsymbol{C}$. apella Monkeys}

The monkeys $(3.5-4 \mathrm{~kg})$ were iron overloaded with intravenous iron dextran as specified in earlier publications to provide about $500 \mathrm{mg}$ of iron per $\mathrm{kg}$ of body weight; 51 the serum transferrin iron saturation rose to between 70 and $80 \%$. At least 20 half-lives, $60 \mathrm{~d}, 52$ elapsed before any of the animals were used in experiments evaluating iron-chelating agents.

\section{Primate Fecal and Urine Samples}

Fecal and urine samples were collected at 24-h intervals and processed as described previously. $46,47,53$ Briefly, the collections began $4 \mathrm{~d}$ prior to the administration of the test drug and continued for an additional $5 \mathrm{~d}$ after the drug was given. Iron concentrations were determined by flame atomic absorption spectroscopy as presented in other publications. ${ }^{46,54}$

\section{Drug Preparation and Administration}

In the iron-clearing experiments the rats were given a single $300 \mu \mathrm{mol} / \mathrm{kg}$ dose of drugs 1-9 orally (po). The compounds were administered as (1) a solution in water (3) or (2) the monosodium salt of the compound of interest (prepared by the addition of 1 equivalent of $\mathrm{NaOH}$ to a suspension of the free acid in distilled water $(\mathbf{1 - 2 , 4 - 9})$.

The drugs were given to the monkeys po at a dose of $75 \mu \mathrm{mol} / \mathrm{kg}(\mathbf{6}, 9)$ or $150 \mu \mathrm{mol} / \mathrm{kg}(\mathbf{1 - 5}$, 7-8). The drugs were prepared as for the rats, except that $\mathbf{2}$ and 7-8 were solubilized in $40 \%$ Cremophor RH-40/water.

\section{Calculation of Iron Chelator Efficiency}

The theoretical iron outputs of the chelators were generated on the basis of a 2:1 complex. The efficiencies in the rats and monkeys were calculated as set forth elsewhere. ${ }^{48}$ Data are presented as the mean \pm the standard error of the mean; $p$-values were generated via a onetailed student's $t$-test, in which the inequality of variances was assumed; and a $p$-value of $<0.05$ was considered significant.

\section{Collection of Tissue Distribution Samples from Rodents}

Male Sprague-Dawley rats (250-350 g) were given a single sc injection of the monosodium salts of 6 and 9 prepared as described above at a dose of $300 \mu \mathrm{mol} / \mathrm{kg}$. At times $0.5,1,2$, and $4 \mathrm{~h}$ after dosing ( $n=3$ rats per time point) the animals were euthanized by exposure to $\mathrm{CO}_{2}$ gas. Blood was obtained via cardiac puncture into vacutainers containing sodium citrate. The blood was centrifuged, and the plasma was separated for analysis. The liver, heart, kidneys, and pancreas were then removed from the animals.

\section{Tissue Analytical Methods}

Tissue samples of animals treated with (S)-4'-(HO)-DADFT (1) and (S)-4'-(HO)-DADFT-PE (3) were prepared for HPLC analysis as previously described. ${ }^{39}$ In the current study, tissues from the $(S)-3^{\prime}-(\mathrm{HO})$-DADFT-PE $(9)$ and $(S)-5^{\prime}$-(HO)-DADFT-PE $(6)$ treated rats were prepared for HPLC analysis by homogenizing them in $0.5 \mathrm{~N} \mathrm{HClO}_{4}$ at a ratio of $1: 3(\mathrm{w} / \mathrm{v})$. Then, as a rinse, $\mathrm{CH}_{3} \mathrm{OH}$ at a ratio of $1: 3(\mathrm{w} / \mathrm{v})$ was added and the mixture was stored at -20 ${ }^{\circ} \mathrm{C}$ for $30 \mathrm{~min}$. This homogenate was centrifuged. The supernatant was diluted with mobile phase $\mathrm{A}$ ( $95 \%$ buffer $\left[25 \mathrm{mM} \mathrm{KH}_{2} \mathrm{PO}_{4}, \mathrm{pH} 3.0\right] / 5 \% \mathrm{CH}_{3} \mathrm{CN}$ ), vortexed, and filtered with a 0.2 $\mu \mathrm{m}$ membrane.

Analytical separation was performed on a Discovery RP Amide $\mathrm{C}_{16}$ HPLC system with UV detection at $310 \mathrm{~nm}$ as described previously. 55,56 Mobile phase and chromatographic conditions were as follows: solvent A, $5 \% \mathrm{CH}_{3} \mathrm{CN} / 95 \%$ buffer; solvent $\mathrm{B}, 60 \% \mathrm{CH}_{3} \mathrm{CN} / 40 \%$ buffer. 
The concentrations were calculated from the peak area fitted to calibration curves by nonweighted least-squares linear regression with Rainin Dynamax HPLC Method Manager software (Rainin Instrument Co.). The method had a detection limit of $0.25 \mu \mathrm{M}$ and was reproducible and linear over a range of $1-1000 \mu \mathrm{M}$.

Tissue distribution data are presented as the mean; $p$-values were generated via a one-tailed student's $t$-test, in which the inequality of variances was assumed and a $p$-value of $<0.05$ was considered significant.

\section{Synthetic Methods}

Compounds $\mathbf{4}$ and $\mathbf{7}$ were synthesized using the method published by this laboratory. 41,49 Reagents were purchased from Aldrich Chemical Co. (Milwaukee, WI), and Fisher Optima grade solvents were routinely used. DMF was distilled under inert atmosphere and THF was distilled from sodium and benzophenone. Reactions were run under a nitrogen atmosphere, and organic extracts were dried with sodium sulfate and filtered. Silica gel 40-63 from SiliCycle, Inc. (Quebec City, QC, Canada) was used for flash column chromatography. C-18 for reverse phase column chromatography was obtained from Sigma Chemical Co. Optical rotations were run at $589 \mathrm{~nm}$ (sodium D line) utilizing a Perkin-Elmer 341 polarimeter, with $c$ being concentration in grams of compound per $100 \mathrm{~mL}$ of solution in chloroform. ${ }^{1} \mathrm{H}$ NMR spectra were recorded at $400 \mathrm{MHz}$ and chemical shifts $(\delta)$ are given in parts per million downfield from tetramethylsilane for $\mathrm{CDCl}_{3}$ (not indicated) or sodium 3-(trimethylsilyl) propionate-2, 2, 3, 3- $d_{4}$ for $\mathrm{D}_{2} \mathrm{O} .{ }^{13} \mathrm{C}$ spectra were run at $100 \mathrm{MHz}$ and chemical shifts $(\delta)$ are given in parts per million referenced to the residual solvent resonance in $\mathrm{CDCl}_{3}(\delta$ 77.16). Coupling constants $(J)$ are in hertz and the base peaks are reported for the ESI-FTICR mass spectra. Elemental analyses were performed by Atlantic Microlabs (Norcross, GA). NOE difference spectra were obtained at $500 \mathrm{MHz}$ and samples were not degassed, were not spun, and the probe temperature was regulated at $27^{\circ} \mathrm{C}$. For 12 the concentration was $15 \mathrm{mg} / 0.6 \mathrm{ml}$ in $\mathrm{CDCl}_{3}$, and for 9 the concentration was $5 \mathrm{mg} / \mathrm{mL} \mathrm{D}_{2} \mathrm{O}$.

Separate spectra to investigate Nuclear Overhauser Effects (NOEs) were acquired by lowpower irradiation off-resonance and then on the resonance for the methylene hydrogens, using a 3 -second presaturation period, a $45^{\circ}$ pulse, and a 3 -second acquisition time. Typically, 100-300 acquisitions were accumulated for each pair of free induction decays before processing with exponential line broadening and Fourier transformation.

NOE difference spectra were presented by subtracting the spectrum with irradiation offresonance from the spectrum with on-resonance presaturation. These difference spectra were then analyzed by integration of the relevant signals. The inverted methylene resonances for the two hydrogens labeled $g$ (Figure 1) and $h$ (Figure 2) were assigned an integral value of -200\%, and the integrals for the positive signal enhancements of the various other resonances were then taken as percent enhancements of their parent signals. Results are reported as the average enhancements from three or four replicates of each difference spectrum.

\section{Isopropyl 2-(2, 5-Dihydroxyphenyl)-4,5-dihydro-4-methyl-4- thiazolecarboxylate (10)}

2-iodopropane $(8.95 \mathrm{~g}, 52.65 \mathrm{mmol})$ and DIEA $(6.79 \mathrm{~g}, 52.65 \mathrm{mmol})$ were successively added to $4(7.40 \mathrm{~g}, 29.25 \mathrm{mmol})$ in DMF $(90 \mathrm{~mL})$ and the solution was stirred at $\mathrm{rt}$ for $72 \mathrm{~h}$. After solvent removal under hivac, the residue was treated with $1: 1,0.5 \mathrm{M}$ citric acid/ saturated $\mathrm{NaCl}$ $(300 \mathrm{~mL})$ and was extracted with EtOAc $(250 \mathrm{~mL}, 2 \times 100 \mathrm{~mL})$. Combined organic extracts were washed with $50 \mathrm{~mL}$ portions of $1 \% \mathrm{NaHSO}_{3}, \mathrm{H}_{2} \mathrm{O}$ and saturated $\mathrm{NaCl}$ and the solution was evaporated. Purification by flash column chromatography using $20 \%$ EtOAc in toluene generated $7.94 \mathrm{~g}$ of $\mathbf{1 0}(92 \%)$ as a yellow oil: $[\alpha]^{20}+41.1^{\circ} ;{ }^{1} \mathrm{H}$ NMR $\delta 1.27$ and $1.29(2 \mathrm{~d}, 6$ $\mathrm{H}, J=5.5), 1.65$ (s, $3 \mathrm{H}), 3.21$ (d, $1 \mathrm{H}, J=11.6$ ), 3.85 (d, $1 \mathrm{H}, J=11.2), 5.09$ (septet, $1 \mathrm{H}, J=$ 
6.4), 6.89 (m, $2 \mathrm{H},) ;{ }^{13} \mathrm{C}$ NMR $\delta 21.70,24.36,40.05,70.02,83.78,115.90,115.94,118.05$, $121.59,148.02,153.11,171.24,172.57$; HRMS m/z calcd for $\mathrm{C}_{14} \mathrm{H}_{18} \mathrm{NO}_{4} \mathrm{~S}, 296.0956(\mathrm{M}+\mathrm{H})$; found, 296.0956. Anal. $\left(\mathrm{C}_{14} \mathrm{H}_{17} \mathrm{NO}_{4} \mathrm{~S}\right) \mathrm{C}, \mathrm{H}, \mathrm{N}$.

\section{Ethyl 2-(2, 3-Dihydroxyphenyl)-4,5-dihydro-4-methyl-4- thiazolecarboxylate (11)}

Iodoethane $(8.61 \mathrm{~g}, 55.20 \mathrm{mmol})$ and DIEA $(7.13 \mathrm{~g}, 55.20 \mathrm{mmol})$ were successively added to $7(7.36 \mathrm{~g}, 29.06 \mathrm{mmol})$ in DMF $(100 \mathrm{~mL})$ and the solution was stirred at $\mathrm{rt}$ for $48 \mathrm{~h}$. After solvent removal under hivac, the residue was treated with $1: 1,0.5 \mathrm{M}$ citric acid/ saturated $\mathrm{NaCl}$ $(300 \mathrm{~mL})$ and was extracted with EtOAc $(200 \mathrm{~mL}, 2 \times 100 \mathrm{~mL})$. Combined organic layers were washed with $150 \mathrm{~mL}$ portions of $1 \% \mathrm{NaHSO}_{3}, \mathrm{H}_{2} \mathrm{O}$ and saturated $\mathrm{NaCl}$ and the solvent was evaporated. Purification by flash column chromatography using 10\% EtOAc in DCM gave $8.01 \mathrm{~g}$ of $\mathbf{1 1}(98 \%)$ as a yellow oil: $[\alpha]^{20}+57.41^{\circ} ;{ }^{1} \mathrm{H}$ NMR $\delta 1.31(\mathrm{t}, 3 \mathrm{H}, J=7.2), 1.68$ (s, 3 H), 3.25 (d, $1 \mathrm{H}, J=11.6), 3.88$ (d, $1 \mathrm{H}, J=11.2), 4.26$ (q, $2 \mathrm{H}, J=7.2), 5.71(\mathrm{br} \mathrm{s}, 1 \mathrm{H}), 6.79$ $(\mathrm{t}, 1 \mathrm{H}, J=7.8), 6.97(\mathrm{dd}, 1 \mathrm{H}, J=8.4,1.2), 7.03(\mathrm{dd}, 1 \mathrm{H}, J=7.8,1.2) ;{ }^{13} \mathrm{C}$ NMR $\delta 14.22$, 24.56, 40.19, 62.17, 83.26, 115.74, 117.88, 119.13, 121.20, 145.11, 146.83, 172.09, 172.69; HRMS m/z calcd for $\mathrm{C}_{13} \mathrm{H}_{15} \mathrm{NO}_{4} \mathrm{SNa}$, 304.0619 (M+Na); found, 304.0625. Anal. $\left(\mathrm{C}_{13} \mathrm{H}_{15} \mathrm{NO}_{4} \mathrm{~S}\right) \mathrm{C}, \mathrm{H}, \mathrm{N}$.

\section{Isopropyl (S)-4,5-Dihydro-2-[2-hydroxy-5-(3,6,9-trioxadecyloxy)phenyl]-4-methyl-4- thiazolecarboxylate (12)}

Tri(ethylene glycol) monomethyl ether $(3.19 \mathrm{~g}, 19.40 \mathrm{mmol})$ and diisopropylazo dicarboxylate $(4.73 \mathrm{~g}, 23.39 \mathrm{mmol})$ were successively added to a solution of $\mathbf{1 0}(5.62 \mathrm{~g}, 19.02 \mathrm{mmol})$ and triphenylphosphine $(5.93 \mathrm{~g}, 22.63 \mathrm{mmol})$ in dry THF $(120 \mathrm{~mL})$ with ice bath cooling. The solution was stirred at room temperature for $5 \mathrm{~h}$ and was maintained at $5{ }^{\circ} \mathrm{C}$ for $16 \mathrm{~h}$. Solvent was removed by rotary evaporation, and $40 \%$ EtOAc/petroleum ether $(100 \mathrm{~mL})$ was added. The solution was kept at $5{ }^{\circ} \mathrm{C}$ for $12 \mathrm{~h}$; the solid formed was filtered. The filtrate was concentrated in vacuo and was purified by column chromatography (50\% EtOAc/petroleum ether) to give $4.36 \mathrm{~g}$ of $\mathbf{1 2}(52 \%)$ as a yellow oil: $[\alpha]^{20}+23.2^{\circ} ;{ }^{1} \mathrm{H}$ NMR $\delta 1.27$ and $1.29(2 \mathrm{~d}$, $6 \mathrm{H}, J=6.2), 1.65(\mathrm{~s}, 3 \mathrm{H}), 3.22(\mathrm{~d}, 1 \mathrm{H}, J=11.2), 3.53-3.58(\mathrm{~m}, 2 \mathrm{H}), 3.64-3.71(\mathrm{~m}, 4 \mathrm{H})$, 3.72-3.77 (m, $2 \mathrm{H}), 3.84$ (t, $2 \mathrm{H}, \mathrm{J}=4.7), 3.87$ (d, $1 \mathrm{H}, \mathrm{J}=11.4$ ), 4.08-4.12 (m, $2 \mathrm{H}), 5.08$ (septet, $1 \mathrm{H}, J=4.0), 6.91-6.96(\mathrm{~m}, 2 \mathrm{H}), 7.01(\mathrm{dd}, 1 \mathrm{H}, J=9.2,3.2), 12.02(\mathrm{br} \mathrm{s}, 1 \mathrm{H}) ;{ }^{13} \mathrm{C} \mathrm{NMR} \delta$ 21.71, 24.37, 40.01, 59.15, 68.52, 69.69, 69.91, 70.68, 70.76, 70.92, 72.03, 83.83, 115.23, 115.82, 118.03, 121.49, 151.17, 153.80, 171.12, 172.13; HRMS m/z calcd for $\mathrm{C}_{21} \mathrm{H}_{32} \mathrm{NO}_{7} \mathrm{~S}$, 442.1899 (M+H); found, 442.1887. Anal. $\left(\mathrm{C}_{21} \mathrm{H}_{31} \mathrm{NO}_{7} \mathrm{~S}\right) \mathrm{C}, \mathrm{H}, \mathrm{N}$.

\section{(S)-4,5-Dihydro-2-[2-hydroxy-5-[2-[(3,6,9-trioxadecyloxy)phenyl]-4-methyl-4- thiazolecarboxylic Acid (6)}

A solution of $50 \%(\mathrm{w} / \mathrm{w}) \mathrm{NaOH}(3.34 \mathrm{~mL}, 94 \mathrm{mmol})$ in $\mathrm{CH}_{3} \mathrm{OH}(34 \mathrm{~mL})$ was added to 12 $(2.14 \mathrm{~g}, 4.85 \mathrm{mmol})$ in $\mathrm{CH}_{3} \mathrm{OH}(70 \mathrm{~mL})$ with ice bath cooling. The reaction mixture was stirred at room temperature for $18 \mathrm{~h}$, and the bulk of the solvent was removed by rotary evaporation. The residue was treated with dilute $\mathrm{NaCl}(100 \mathrm{~mL})$ and was extracted with ether $(3 \times 50 \mathrm{~mL})$. The basic aqueous phase was cooled in ice, acidified with $2 \mathrm{~N} \mathrm{HCl}$ to $\mathrm{pH}=2$, and extracted with EtOAc $(3 \times 100 \mathrm{~mL})$. After the EtOAc layers were washed with saturated $\mathrm{NaCl}(100 \mathrm{~mL})$, glassware that was presoaked in $3 \mathrm{~N} \mathrm{HCl}$ for 15 min was employed henceforth. After solvent removal by rotary evaporation, $1.88 \mathrm{~g}$ of $\mathbf{6}(97 \%)$ was obtained as an orange oil: $[\alpha]^{20}$ $+40.0^{\circ} ;{ }^{1} \mathrm{H}$ NMR $\left(\mathrm{D}_{2} \mathrm{O}\right) \delta 1.72(\mathrm{~s}, 3 \mathrm{H}), 3.26(\mathrm{~d}, 1 \mathrm{H}, J=11.2), 3.38(\mathrm{~s}, 3 \mathrm{H}), 3.54-3.58(\mathrm{~m}, 2 \mathrm{H})$, 3.64-3.71 (m, 4 H), 3.72-3.76 (m, 2 H), 4.07-4.11 (m, 3 H), 6.91-6.95 (m, $2 \mathrm{H}), 7.01$ (dd, 1 H, $J=9.0,3.0) ;{ }^{13} \mathrm{C}$ NMR $\delta 24.46,40.04,59.04,68.40,69.86,70.48,70.62,70.80,71.91,83.44$, $115.21,115.65,118.09,121.63,151.12,153.69,171.83,176.18 ; \mathrm{HRMS} \mathrm{m} / \mathrm{z}$ calcd for $\mathrm{C}_{18} \mathrm{H}_{26} \mathrm{NO}_{7} \mathrm{~S}, 400.1429(\mathrm{M}+\mathrm{H})$; found, 400.1416 . 


\section{Ethyl (S)-4,5-Dihydro-2-[2-hydroxy-3-(3,6,9-trioxadecyloxy)phenyl]-4-methyl-4-thiazole- carboxylate (13)}

Tri(ethylene glycol) monomethyl ether $(1.70 \mathrm{~g}, 10.36 \mathrm{mmol})$ and diisopropylazo dicarboxylate $(2.53 \mathrm{~g}, 12.50 \mathrm{mmol})$ were successively added to a solution of $\mathbf{1 1}(3.0 \mathrm{~g}, 10.16 \mathrm{mmol})$ and triphenylphosphine $(3.17 \mathrm{~g}, 12.09 \mathrm{mmol})$ in dry THF $(60 \mathrm{~mL})$ with ice bath cooling. The solution was stirred at room temperature for $8 \mathrm{~h}$ and was maintained at $5{ }^{\circ} \mathrm{C}$ for $40 \mathrm{~h}$. Solvent was removed by rotary evaporation, and $40 \%$ EtOAc/petroleum ether $(50 \mathrm{~mL})$ was added. The solution was kept at $5{ }^{\circ} \mathrm{C}$ for $12 \mathrm{~h}$; the solid formed was filtered. The filtrate was concentrated in vacuo and was purified by column chromatography eluting with $50 \%$ EtOAc/petroleum ether to give $1.08 \mathrm{~g}$ of $\mathbf{1 3}(25 \%)$ as an orange oil. Analytical sample was purified on C-18 reverse phase column eluting with equal volumes of $50 \%$ aq. $\mathrm{MeOH}$ and $40 \%$ aq. $\mathrm{MeOH}$, respectively: $[\alpha]^{20}+40.0^{\circ} ;{ }^{1} \mathrm{H}$ NMR $\delta 1.30(\mathrm{t}, 3 \mathrm{H}, J=7.2), 1.66(\mathrm{~s}, 3 \mathrm{H}), 3.23(\mathrm{~d}, 1 \mathrm{H}, J=$ 11.2), 3.38 (s, $3 \mathrm{H}), 3.52-3.58(\mathrm{~m}, 2 \mathrm{H}), 3.63-3.71(\mathrm{~m}, 4 \mathrm{H}), 3.74-3.79(\mathrm{~m}, 2 \mathrm{H}), 3.88(\mathrm{~d}, 1 \mathrm{H}$, $J=11.6), 3.91(\mathrm{t}, 2 \mathrm{H}, J=5.0), 4.20-4.26(\mathrm{~m}, 4 \mathrm{H}), 6.79(\mathrm{t}, 1 \mathrm{H}, J=7.6), 7.01-7.07$ (m, 2 $\mathrm{H}) ;{ }^{13} \mathrm{C}$ NMR $\delta 14.18,24.47,39.96,59.10,62.07,68.95,69.79,70.60,70.70,70.91,71.99$, 83.48, 116.42, 117.62, 118.29, 122.71, 147.72, 150.35, 171.70, 172.69; HRMS m/z calcd for $\mathrm{C}_{20} \mathrm{H}_{29} \mathrm{NO}_{7} \mathrm{SNa}, 450.1562(\mathrm{M}+\mathrm{Na})$; found, 450.1568. Anal. $\left(\mathrm{C}_{20} \mathrm{H}_{29} \mathrm{NO}_{7} \mathrm{~S}\right) \mathrm{C}, \mathrm{H}, \mathrm{N}$.

\section{(S)-4,5-Dihydro-2-[2-hydroxy-3-[2-[(3,6,9-trioxadecyloxy)phenyl]-4-methyl-4- thiazolecarboxylic Acid (9)}

A solution of $50 \%$ (w/w) $\mathrm{NaOH}(13.88 \mathrm{~mL}, 266.02 \mathrm{mmol})$ in $\mathrm{CH}_{3} \mathrm{OH}(120 \mathrm{~mL})$ was added to $13(8.89 \mathrm{~g}, 20.80 \mathrm{mmol})$ in $\mathrm{CH}_{3} \mathrm{OH}(280 \mathrm{~mL})$ with ice bath cooling. The reaction mixture was stirred at room temperature for $6 \mathrm{~h}$, and the bulk of the solvent was removed by rotary evaporation. The residue was treated with dilute $\mathrm{NaCl}(300 \mathrm{~mL})$ and the basic aqueous phase was cooled in ice, acidified with $2 \mathrm{~N} \mathrm{HCl}$ to $\mathrm{pH}=2$, and extracted with EtOAc $(4 \times 150 \mathrm{~mL})$. After the EtOAc layers were washed with saturated $\mathrm{NaCl}(300 \mathrm{~mL})$, glassware that was presoaked in $3 \mathrm{~N} \mathrm{HCl}$ for 15 min was employed henceforth. After solvent removal by rotary evaporation, purification was done on $\mathrm{C}-18$ reverse phase column, eluting with $50 \%$ aq. methanol and lyophilized to furnish $4.98 \mathrm{~g}$ of $\mathbf{9}(60 \%)$ as an orange oil: $[\alpha]^{20}+61.9^{\circ} ;{ }^{1} \mathrm{H}$ NMR $\left(\mathrm{D}_{2} \mathrm{O}\right) \delta 1.77(\mathrm{~s}, 3 \mathrm{H}), 3.35(\mathrm{~s}, 3 \mathrm{H}), 3.56-3.62(\mathrm{~m}, 3 \mathrm{H}), 3.64-3.73(\mathrm{~m}, 4 \mathrm{H}), 3.75-3.89(\mathrm{~m}, 2 \mathrm{H})$, 3.92-3.96 (m, $2 \mathrm{H}), 3.99$ (d, $1 \mathrm{H}, J=11.6), 4.25-4.31$ (m, $2 \mathrm{H}), 6.99$ (t, $1 \mathrm{H}, J=8.2), 7.26-7.33$ (m, $2 \mathrm{H}) ;{ }^{13} \mathrm{C}$ NMR $\delta 24.52,39.93,59.07,69.04,69.83,70.49,70.64,70.86,71.97,83.21$, $116.33,117.94,118.50,122.80,147.67,150.24,172.38,176.10 ;$ HRMS $\mathrm{m} / \mathrm{z}$ calcd for $\mathrm{C}_{18} \mathrm{H}_{26} \mathrm{NO}_{7} \mathrm{~S}, 400.1429(\mathrm{M}+\mathrm{H})$; found, 400.1413 .

\section{Supplementary Material}

Refer to Web version on PubMed Central for supplementary material.

\section{Acknowledgements}

Funding was provided by the National Institutes of Health Grant No. R37-DK49108. We thank Elizabeth M. Nelson, Tanaya Lindstrom, and Katie Ratliff-Thompson for their technical assistance and Carrie A. Blaustein for her editorial and organizational support. The authors gratefully acknowledge the National Science Foundation for funding through the National High Magnetic Field Laboratory, which supported our NOE difference studies at the Advanced Magnetic Resonance Imaging and Spectroscopy (AMRIS) facility in the McKnight Brain Institute of the University of Florida.

\section{References}

1. Brittenham, GM. Disorders of Iron Metabolism: Iron Deficiency and Overload. In: Hoffman, R.; Benz, EJ.; Shattil, SJ.; Furie, B.; Cohen, HJ., et al., editors. Hematology: Basic Principles and Practice. 3rd. Churchill Livingstone; New York: 2000. p. 397-428. 
2. Olivieri NF, Brittenham GM. Iron-chelating Therapy and the Treatment of Thalassemia. Blood 1997;89:739-761. [PubMed: 9028304]

3. Vichinsky EP. Current Issues with Blood Transfusions in Sickle Cell Disease. Semin Hematol 2001;38:14-22. [PubMed: 11206956]

4. Kersten MJ, Lange R, Smeets ME, Vreugdenhil G, Roozendaal KJ, Lameijer W, Goudsmit R. LongTerm Treatment of Transfusional Iron Overload with the Oral Iron Chelator Deferiprone (L1): A Dutch Multicenter Trial. Ann Hematol 1996;73:247-252. [PubMed: 8959943]

5. Conrad ME, Umbreit JN, Moore EG. Iron Absorption and Transport. Am J Med Sci 1999;318:213229. [PubMed: 10522550]

6. Lieu PT, Heiskala M, Peterson PA, Yang Y. The Roles of Iron in Health and Disease. Mol Aspects Med 2001;22:1-87. [PubMed: 11207374]

7. Angelucci E, Brittenham GM, McLaren CE, Ripalti M, Baronciani D, Giardini C, Galimberti M, Polchi P, Lucarelli G. Hepatic Iron Concentration and Total Body Iron Stores in Thalassemia Major. N Engl J Med 2000;343:327-331. [PubMed: 10922422]

8. Bonkovsky HL, Lambrecht RW. Iron-Induced Liver Injury. Clin Liver Dis 2000;4:409-429. vi-vii. [PubMed: 11232198]

9. Pietrangelo A. Mechanism of Iron Toxicity. Adv Exp Med Biol 2002;509:19-43. [PubMed: 12572987]

10. Cario H, Holl RW, Debatin KM, Kohne E. Insulin Sensitivity and $\beta$-Cell Secretion in Thalassaemia Major with Secondary Haemochromatosis: Assessment by Oral Glucose Tolerance Test. Eur J Pediatr 2003;162:139-146. [PubMed: 12655415]

11. Wojcik JP, Speechley MR, Kertesz AE, Chakrabarti S, Adams PC. Natural History of C282Y Homozygotes for Hemochromatosis. Can J Gastroenterol 2002;16:297-302. [PubMed: 12045778]

12. Brittenham GM, Griffith PM, Nienhuis AW, McLaren CE, Young NS, Tucker EE, Allen CJ, Farrell DE, Harris JW. Efficacy of Deferoxamine in Preventing Complications of Iron Overload in Patients with Thalassemia Major. N Engl J Med 1994;331:567-573. [PubMed: 8047080]

13. Zurlo MG, De Stefano P, Borgna-Pignatti C, Di Palma A, Piga A, Melevendi C, Di Gregorio F, Burattini MG, Terzoli S. Survival and Causes of Death in Thalassaemia Major. Lancet 1989;2:2730. [PubMed: 2567801]

14. Raymond KN, Carrano CJ. Coordination Chemistry and Microbial Iron Transport. Acc Chem Res 1979;12:183-190.

15. Byers BR, Arceneaux JE. Microbial Iron Transport: Iron Acquisition by Pathogenic Microorganisms. Met Ions Biol Syst 1998;35:37-66. [PubMed: 9444759]

16. Kalinowski DS, Richardson DR. The Evolution of Iron Chelators for the Treatment of Iron Overload Disease and Cancer. Pharmacol Rev 2005;57:547-583. [PubMed: 16382108]

17. Bergeron RJ. Iron: A Controlling Nutrient in Proliferative Processes. Trends Biochem Sci 1986;11:133-136.

18. Theil EC, Huynh BH. Ferritin Mineralization: Ferroxidation and Beyond. J Inorg Biochem 1997;67:30.

19. Ponka P, Beaumont C, Richardson DR. Function and Regulation of Transferrin and Ferritin. Semin Hematol 1998;35:35-54. [PubMed: 9460808]

20. Graf E, Mahoney JR, Bryant RG, Eaton JW. Iron-Catalyzed Hydroxyl Radical Formation. Stringent Requirement for Free Iron Coordination Site. J Biol Chem 1984;259:3620-3624. [PubMed: 6323433]

21. Halliwell B. Free Radicals and Antioxidants: A Personal View. Nutr Rev 1994;52:253-265. [PubMed: 7970288]

22. Halliwell, B. Iron, Oxidative Damage, and Chelating Agents. In: Bergeron, RJ.; Brittenham, GM., editors. The Development of Iron Chelators for Clinical Use. CRC; Boca Raton: 1994. p. 33-56.

23. Koppenol, W. Kinetics and Mechanism of the Fenton Reaction: Implications for Iron Toxicity. In: Badman, DG.; Bergeron, RJ.; Brittenham, GM., editors. Iron Chelators: New Development Strategies. Saratoga; Ponte Vedra Beach, FL: 2000. p. 3-10.

24. Babbs CF. Oxygen Radicals in Ulcerative Colitis. Free Radic Biol Med 1992;13:169-181. [PubMed: 1355459]

25. Hazen SL, d'Avignon A, Anderson MM, Hsu FF, Heinecke JW. Human Neutrophils Employ the Myeloperoxidase-Hydrogen Peroxide-Chloride System to Oxidize $\alpha$-Amino Acids to a Family of 
Reactive Aldehydes. Mechanistic Studies Identifying Labile Intermediates along the Reaction Pathway. J Biol Chem 1998;273:4997-5005. [PubMed: 9478947]

26. Bergeron, RJ.; McManis, JS.; Weimar, WR.; Wiegand, J.; Eiler-McManis, E. Iron Chelators and Therapeutic Uses. In: Abraham, DA., editor. Burger's Medicinal Chemistry. 6th. Wiley; New York: 2003. p. 479-561.

27. Brittenham GM. Iron Chelators and Iron Toxicity. Alcohol 2003;30:151-158. [PubMed: 12957300]

28. Bickel H, Hall GE, Keller-Schierlein W, Prelog V, Vischer E, Wettstein A. Metabolic Products of Actinomycetes. XXVII. Constitutional Formula of Ferrioxamine B. Helv Chim Acta 1960;43:2129_ 2138.

29. Giardina PJ, Grady RW. Chelation Therapy in $\beta$-Thalassemia: An Optimistic Update. Semin Hematol 2001;38:360-366. [PubMed: 11605171]

30. Pippard MJ. Desferrioxamine-Induced Iron Excretion in Humans. Bailliere's Clin Haematol 1989;2:323-343. [PubMed: 2660931]

31. Hoffbrand AV, Al-Refaie F, Davis B, Siritanakatkul N, Jackson BFA, Cochrane J, Prescott E, Wonke B. Long-term Trial of Deferiprone in 51 Transfusion-Dependent Iron Overloaded Patients. Blood 1998;91:295-300. [PubMed: 9414297]

32. Olivieri NF. Long-term Therapy with Deferiprone. Acta Haematol 1996;95:37-48. [PubMed: 8604585]

33. Olivieri NF, Brittenham GM, McLaren CE, Templeton DM, Cameron RG, McClelland RA, Burt AD, Fleming KA. Long-Term Safety and Effectiveness of Iron-Chelation Therapy with Deferiprone for Thalassemia Major. N Engl J Med 1998;339:417-423. [PubMed: 9700174]

34. Richardson DR. The Controversial Role of Deferiprone in the Treatment of Thalassemia. J Lab Clin Med 2001;137:324-329. [PubMed: 11329529]

35. Nisbet-Brown E, Olivieri NF, Giardina PJ, Grady RW, Neufeld EJ, Sechaud R, Krebs-Brown AJ, Anderson JR, Alberti D, Sizer KC, Nathan DG. Effectiveness and Safety of ICL670 in Iron-Loaded Patients with Thalassaemia: a Randomised, Double-Blind, Placebo-Controlled, Dose-Escalation Trial. Lancet 2003;361:1597-1602. [PubMed: 12747879]

36. Galanello R, Piga A, Alberti D, Rouan MC, Bigler H, Séchaud R. Safety, Tolerability, and Pharmacokinetics of ICL670, a New Orally Active Iron-Chelating Agent in Patients with Transfusion-Dependent Iron Overload Due to $\beta$-Thalassemia. J Clin Pharmacol 2003;43:565-572. [PubMed: 12817519]

37. Cappellini MD. Iron-chelating therapy with the new oral agent ICL670 (Exjade). Best Pract Res Clin Haematol 2005;18:289-298. [PubMed: 15737891]

38. Exjade Prescribing Information. May. 2007 http://www.pharma.us.novartis.com/product/pi/pdf/exjade.pdf

39. Bergeron RJ, Wiegand J, McManis JS, Vinson JRT, Yao H, Bharti N, Rocca JR. (S)-4,5-Dihydro-2(2-hydroxy-4-hydroxyphenyl)-4-methyl-4-thiazolecarboxylic Acid Polyethers: A Solution to Nephrotoxicity. J Med Chem 2006;49:2772-2783. [PubMed: 16640338]

40. Bergeron RJ, Wiegand J, McManis JS, Bussenius J, Smith RE, Weimar WR. Methoxylation of Desazadesferrithiocin Analogues: Enhanced Iron Clearing Efficiency. J Med Chem 2003;46:1470_ 1477. [PubMed: 12672247]

41. Bergeron RJ, Wiegand J, McManis JS, Bharti N. The Design, Synthesis, and Evaluation of OrganSpecific Iron Chelators. J Med Chem 2006;49:7032-7043. [PubMed: 17125256]

42. Naegeli HU, Zähner H. Metabolites of Microorganisms. Part 193. Ferrithiocin. Helv Chim Acta 1980;63:1400-1406.

43. Hahn FE, McMurry TJ, Hugi A, Raymond KN. Coordination Chemistry of Microbial Iron Transport. 42. Structural and Spectroscopic Characterization of Diastereomeric $\mathrm{Cr}$ (III) and $\mathrm{Co}$ (III) Complexes of Desferriferrithiocin. J Am Chem Soc 1990;112:1854-1860.

44. Anderegg G, Räber M. Metal Complex Formation of a New Siderophore Desferrithiocin and of Three Related Ligands. J Chem Soc Chem Commun 1990:1194-1196.

45. Bergeron RJ, Wiegand J, Dionis JB, Egli-Karmakka M, Frei J, Huxley-Tencer A, Peter HH. Evaluation of Desferrithiocin and Its Synthetic Analogues as Orally Effective Iron Chelators. J Med Chem 1991;34:2072-2078. [PubMed: 2066978] 
46. Bergeron RJ, Streiff RR, Wiegand J, Vinson JRT, Luchetta G, Evans KM, Peter H, Jenny HB. A Comparative Evaluation of Iron Clearance Models. Ann N Y Acad Sci 1990;612:378-393. [PubMed: 2127168]

47. Bergeron RJ, Streiff RR, Creary EA, Daniels RD Jr, King W, Luchetta G, Wiegand J, Moerker T, Peter HH. A Comparative Study of the Iron-Clearing Properties of Desferrithiocin Analogues with Desferrioxamine B in a Cebus Monkey Model. Blood 1993;81:2166-2173. [PubMed: 8471775]

48. Bergeron RJ, Wiegand J, McManis JS, McCosar BH, Weimar WR, Brittenham GM, Smith RE. Effects of C-4 Stereochemistry and C-4' Hydroxylation on the Iron Clearing Efficiency and Toxicity of Desferrithiocin Analogues. J Med Chem 1999;42:2432-2440. [PubMed: 10395484]

49. Bergeron RJ, Wiegand J, McManis JS, Weimar WR, Park JH, Eiler-McManis E, Bergeron J, Brittenham GM. Partition-Variant Desferrithiocin Analogues: Organ Targeting and Increased Iron Clearance. J Med Chem 2005;48:821-831. [PubMed: 15689166]

50. Ostergaard J, Schou C, Larsen C, Heegaard NH. Evaluation of Capillary Electrophoresis-Frontal Analysis for the Study of Low Molecular Weight Drug-Human Serum Albumin Interactions. Electrophoresis 2002;23:2842-2853. [PubMed: 12207290]

51. Bergeron RJ, Streiff RR, Wiegand J, Luchetta G, Creary EA, Peter HH. A Comparison of the IronClearing Properties of 1,2-Dimethyl-3-hydroxypyrid-4-one, 1,2-Diethyl-3-hydroxypyrid-4-one, and Deferoxamine. Blood 1992;79:1882-1890. [PubMed: 1558978]

52. Wood JK, Milner PF, Pathak UN. The Metabolism of Iron-dextran Given as a Total-dose Infusion to Iron Deficient Jamaican Subjects. Br J Haematol 1968;14:119-129. [PubMed: 5638259]

53. Bergeron RJ, Wiegand J, Brittenham GM. HBED: A Potential Alternative to Deferoxamine for IronChelating Therapy. Blood 1998;91:1446-1452. [PubMed: 9454776]

54. Bergeron RJ, Wiegand J, Wollenweber M, McManis JS, Algee SE, Ratliff-Thompson K. Synthesis and Biological Evaluation of Naphthyldesferrithiocin Iron Chelators. J Med Chem 1996;39:15751581. [PubMed: 8648596]

55. Bergeron RJ, Wiegand J, Weimar WR, McManis JS, Smith RE, Abboud KA. Iron Chelation Promoted by Desazadesferrithiocin Analogues: An Enantioselective Barrier. Chirality 2003;15:593-599. [PubMed: 12840823]

56. Bergeron RJ, Wiegand J, Ratliff-Thompson K, Weimar WR. The Origin of the Differences in $(R)$ and (S)-Desmethyldesferrithiocin: Iron-Clearing Properties. Ann N Y Acad Sci 1998;850:202-216. [PubMed: 9668541]

\section{Glossary}

\section{DADFT}

desazadesferrithiocin [(S)-4,5-dihydro-2-(2-hydroxyphenyl)-4-methyl-4thiazolecarboxylic acid

\section{ICE}

iron-clearing efficiency

$\log P_{\text {app }}$

octanol-water partition coefficient (lipophilicity)

DFO

desferrioxamine B mesylate

DFT

desferrithiocin [(S)-4,5-dihydro-2-(3-hydroxy-2-pyridinyl)-4-methyl-4thiazolecarboxylic acid]

NOE

Nuclear Overhauser Effect

PR

performance ratio ( $\left.\mathrm{ICE}_{\text {primates }} / \mathrm{ICE}_{\text {rodents }}\right)$ 


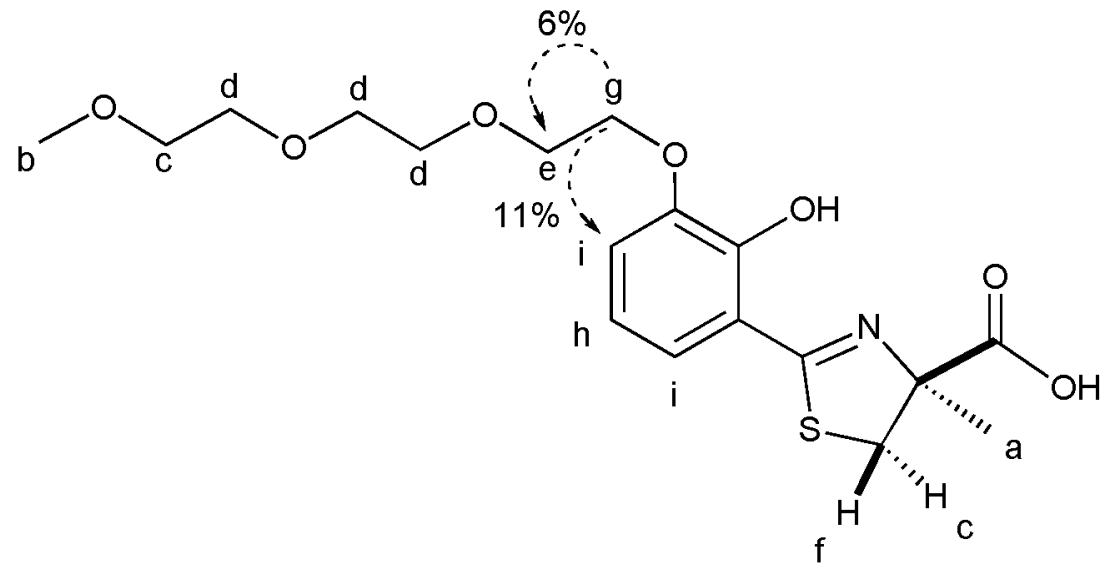

3.75-3.89 (m, $2 \mathrm{H})$

3.92-3.96 (m, $2 \mathrm{H})$

$3.99(\mathrm{~d}, 1 \mathrm{H}, \mathrm{J}=11.6)$

4.25-4.31 (m, $2 \mathrm{H})$

$6.99(\mathrm{t}, 1 \mathrm{H}, \mathrm{J}=8.2)$

7.26-7.33 (two d, $2 \mathrm{H}$ )

Figure 1.

${ }^{1} \mathrm{H}$ resonances and pertinent homonuclear NOE correlations for $(S)-3$ '-(HO)-DADFT-PE (9); the percent NOE is indicated next to the dotted lines. 


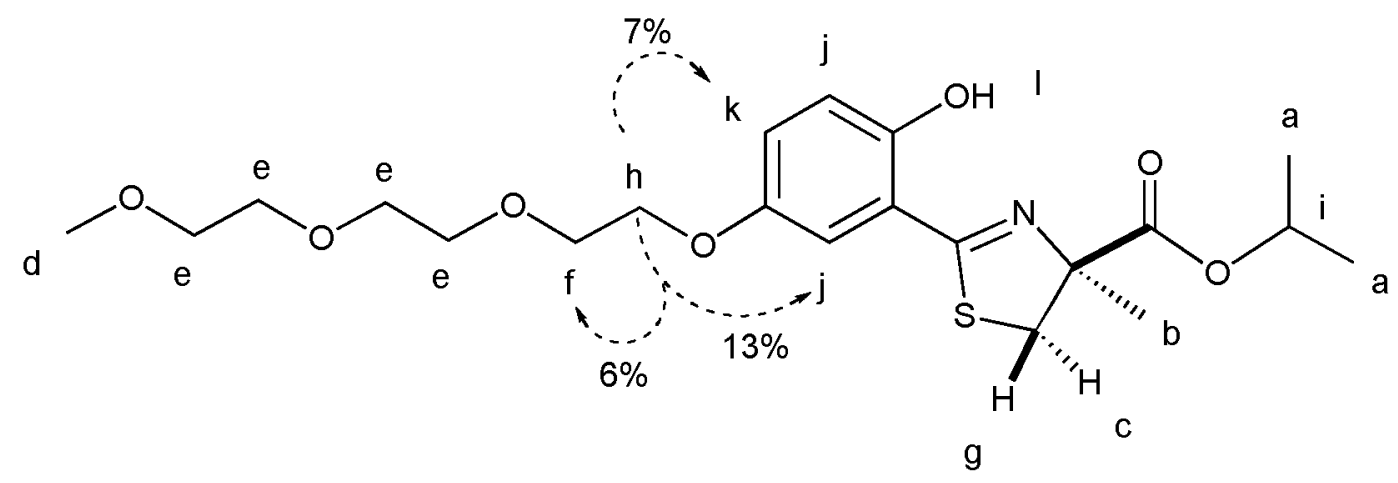

${ }^{1} \mathrm{H}$ Assignment (12)

(multiplicity, integration, coupling constant in $\mathrm{Hz}$ )

$\begin{array}{ll}\text { a } & 1.27(\mathrm{~d}, 3 \mathrm{H}, J=6.3) \\ \mathrm{a} & 1.29(\mathrm{~d}, 3 \mathrm{H}, J=6.3) \\ \mathrm{b} & 1.66(\mathrm{~s}, 3 \mathrm{H}) \\ \mathrm{c} & 3.23(\mathrm{~d}, 1 \mathrm{H}, J=11.3) \\ \mathrm{d} & 3.38(\mathrm{~s}, 3 \mathrm{H}) \\ \mathrm{e} & 3.53-3.58(\mathrm{~m}, 2 \mathrm{H}) \\ \mathrm{e} & 3.64-3.67(\mathrm{~m}, 2 \mathrm{H}) \\ \mathrm{e} & 3.68-3.71(\mathrm{~m}, 2 \mathrm{H}) \\ \mathrm{e} & 3.72-3.76(\mathrm{~m}, 2 \mathrm{H}) \\ \mathrm{f} & 3.84(\mathrm{t}, 2 \mathrm{H}, J=4.7) \\ \mathrm{g} & 3.87(\mathrm{~d}, 1 \mathrm{H}, J=11.4) \\ \mathrm{h} & 4.10(\mathrm{t}, 2 \mathrm{H}, J=4.7) \\ \mathrm{i} & 5.09(\mathrm{septet}, 1 \mathrm{H}, J=6.2) \\ \mathrm{j} & 6.91-6.96(\mathrm{tw}, \mathrm{d}, 2 \mathrm{H}) \\ \mathrm{k} & 7.01(\mathrm{dd}, 1 \mathrm{H}, \mathrm{J}=9.2,3.2) \\ \mathrm{l} & 12.02(\mathrm{br} \mathrm{s}, 1 \mathrm{H})\end{array}$

Figure 2.

${ }^{1} \mathrm{H}$ resonances and pertinent homonuclear NOE correlations for $(S)-5$ '-(HO)-DADFT-PE-iPrE (12); the percent NOE is indicated next to the dotted lines. 


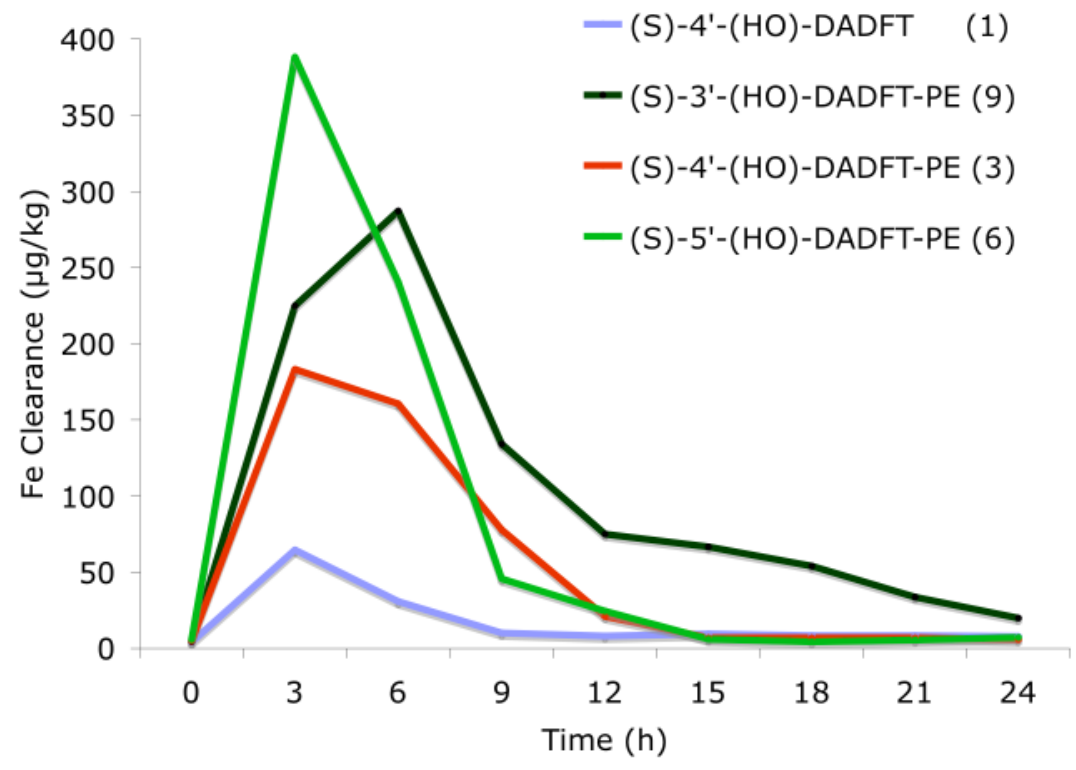

Figure 3.

Biliary ferrokinetics of rats treated with DADFT analogues 1, 3, 6 and 9 given po at a dose of $300 \mu \mathrm{mol} / \mathrm{kg}$. The iron clearance ( $y$-axis) is reported as $\mu \mathrm{g}$ of iron per $\mathrm{kg}$ body weight. 
(S)-4'-(HO)-DADFT (1)

(S)-3'-(HO)-DADFT-PE (9)

(S)-4'-(HO)-DADFT-PE (3)

(S)-5'-(HO)-DADFT-PE (6)
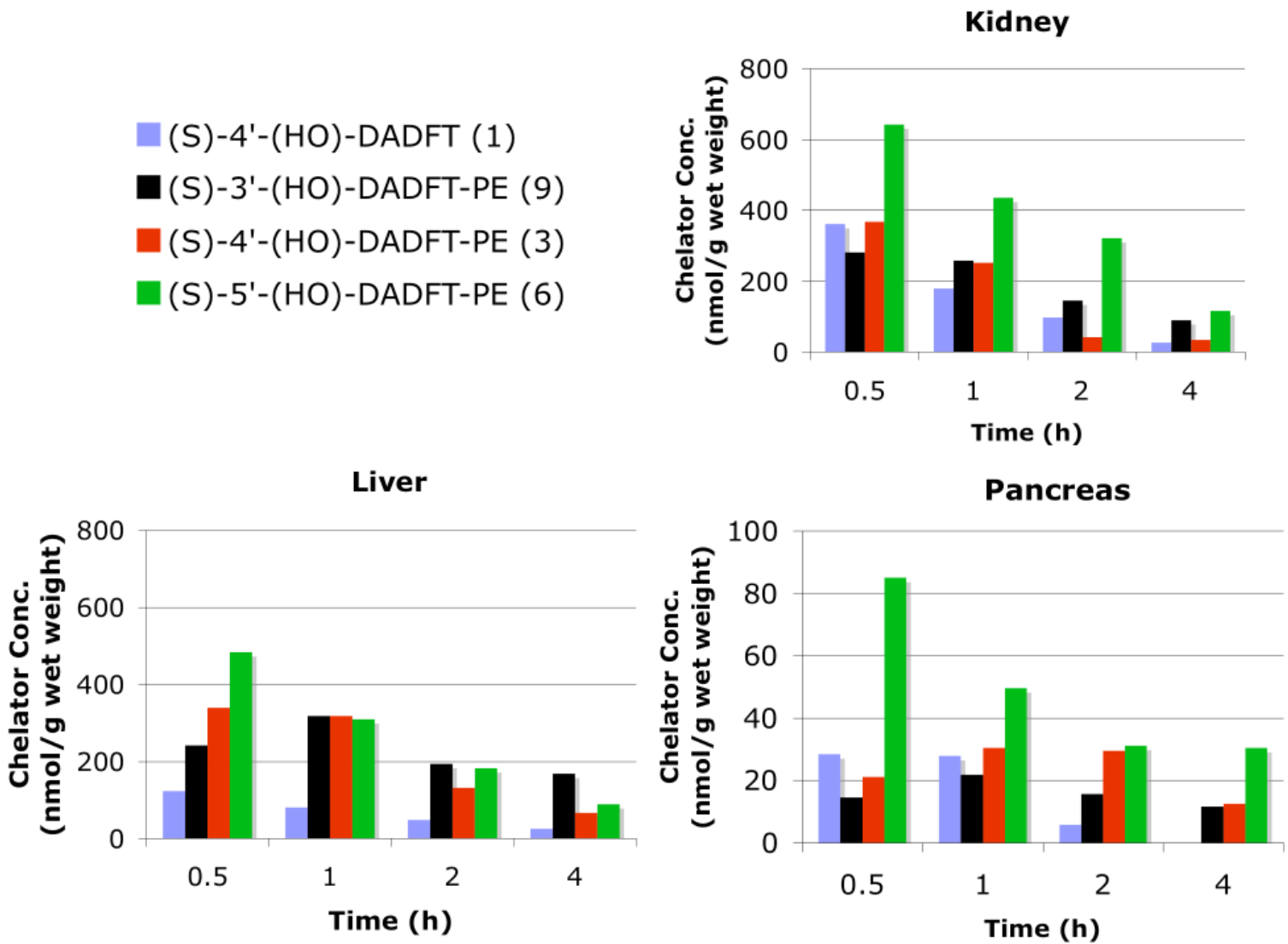

Heart
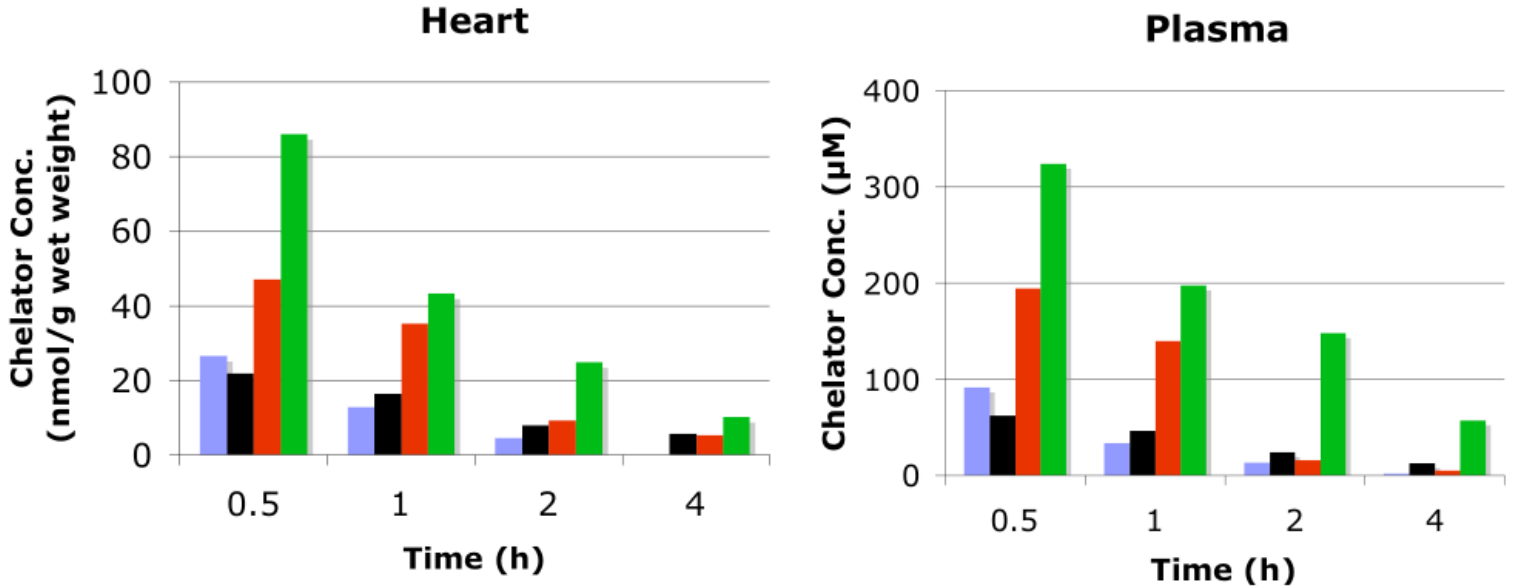

Figure 4.

Tissue distribution in plasma, kidney, liver, heart and pancreas of rats treated with DADFT analogues 1, 3, 6 and 9 given sc at a dose of $300 \mu \mathrm{mol} / \mathrm{kg}$. The concentrations ( $y$-axis) are reported as $\mu \mathrm{M}$ (plasma) or as nmol compound per g wet weight of tissue. For all time points, $n=3$. 
<smiles>[R]OC(=O)[C@]1(C)CSC(c2cc([R])cc([R2])c2O)=N1</smiles>

$4 \mathrm{R}_{2}=\mathrm{H}, \mathrm{R}_{1}=\mathrm{OH}, \mathrm{R}=\mathrm{H}$

$7 \mathrm{R}_{\mathbf{2}}=\mathrm{OH}, \mathrm{R}_{\mathbf{1}}=\mathrm{H}, \mathrm{R}=\mathrm{H}$<smiles>[R]O[C@]1(C)CSC(c2cccc(OCCOCCOCCOC)c2O)=N1</smiles>

$13 \mathrm{R}=\mathrm{Et}$

$9 \mathrm{R}=\mathrm{H}$
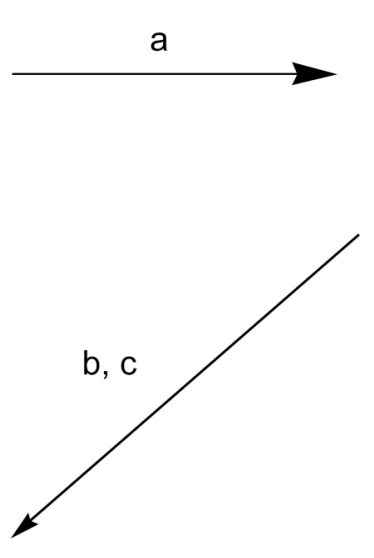<smiles>[R]OC(=O)[C@]1(C)CSC(c2cc([R])cc([R])c2O)=N1</smiles>

$10 R_{2}=H, R_{1}=O H, R=i P r$

$11 R_{2}=O H, R_{1}=H, R=E t$<smiles>[R]OC(=O)[C@]1(C)CSC(c2cc(OCCOCCOCCOC)ccc2O)=N1</smiles>

$12 \mathrm{R}=\mathrm{iPr}$

$6 \mathrm{R}=\mathrm{H}$

Scheme 1.

Synthesis of $(S)-5^{\prime}-(\mathrm{OH})-D A D F T-P E(6)$ and $(S)-3$ '-(OH)-DADFT-PE (9).

${ }^{a}$ Reagents (a) EtI / i-Pr I(1.8 equiv), DIEA(1.8 equiv), DMF, rt, 8d, quant.; (b) $\mathrm{CH}_{3}[\mathrm{O}$

$\left.\left(\mathrm{CH}_{2}\right)_{2}\right]_{3} \mathrm{OH}$ (1.0 equiv), DIPAD(1.2 equiv), $\mathrm{PPH}_{3}$ (1.2 equiv), dry THF, $5{ }^{\circ} \mathrm{C}, 1 \mathrm{~d}, 52 \%(12)$, $25 \%$ (13); (c) $50 \% \mathrm{NaOH}$ (13 equiv), $\mathrm{CH}_{3} \mathrm{OH}, 2 \mathrm{~N} \mathrm{HCl}, \mathrm{rt}, 97 \%(6), 60 \%$ (9). 
Table 1

Iron-Clearing Activity of Desferrithiocin Analogues When Administered Orally to Rodents and the Partition Coefficients of the Compounds

\begin{tabular}{lcc}
\hline Desferrithiocin Analogue & Iron-Clearing Efficiency (\%) ${ }^{\boldsymbol{a}}$ & $\log \boldsymbol{P}_{\text {app }}^{\boldsymbol{b}}$ \\
\hline
\end{tabular}

(S)-4'-(HO)-DADFT, 1

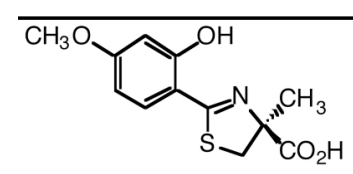

(S)-4'-( $\left.\mathrm{CH}_{3} \mathrm{O}\right)$-DADFT, 2

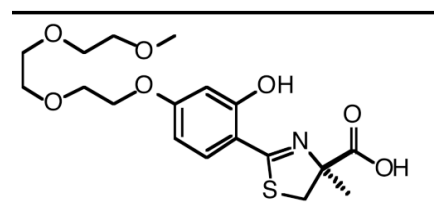

(S)-4'-(HO)-DADFT-PE, 3

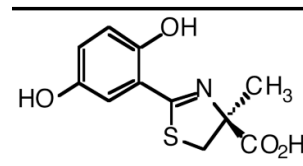

$$
\begin{gathered}
1.0 \pm 0.9^{d} \\
{[99 / 1]}
\end{gathered}
$$

(S)-5'-(HO)-DADFT, 4

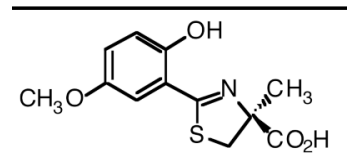

$$
\begin{gathered}
6.3 \pm 1.2^{d} \\
{[95 / 5]}
\end{gathered}
$$

(S)-5'-( $\left.\mathrm{CH}_{3} \mathrm{O}\right)$-DADFT, 5

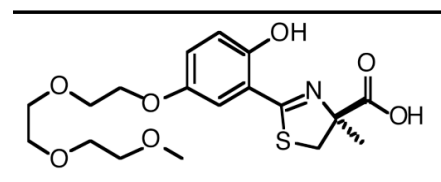

$8.0 \pm 1.8$

(S)-5'-(HO)-DADFT-PE, 6

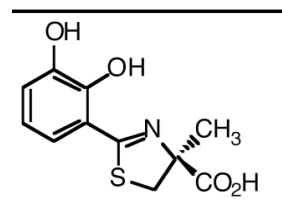

(S)-3'-(HO)-DADFT, 7

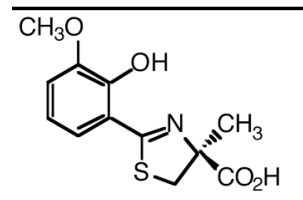


Desferrithiocin Analogue

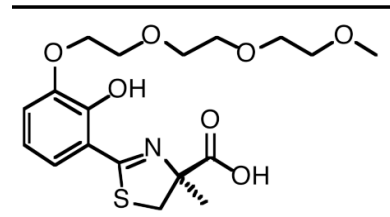

(S)-3'-(HO)-DADFT-PE, 9

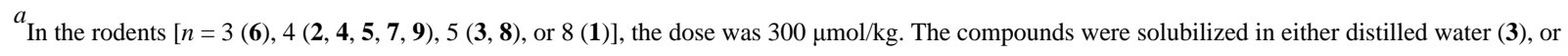
were given as their monosodium salts, prepared by the addition of 1 equivalent of $\mathrm{NaOH}$ to a suspension of the free acid in distilled water $(\mathbf{1}, \mathbf{2}, \mathbf{4 - 9})$. The efficiency of each compound was calculated by subtracting the iron excretion of control animals from the iron excretion of the treated animals. This number was then divided by the theoretical output; the result is expressed as a percent. The relative percentages of the iron excreted in the bile and urine are in brackets.

$b_{\mathrm{D}}$ expressed as the $\log$ of the fraction in the octanol layer $(\log P$ app); measurements were done in TRIS buffer, pH 7.4, using a "shake flask" direct method. The values obtained for compounds $\mathbf{1}$ and $\mathbf{2}$ are from ${ }^{\text {ref }} 40$; the value for $\mathbf{3}$ is from ${ }^{\text {ref } 39}$; the values for $\mathbf{4}$ and $\mathbf{5}$ are from ${ }^{\text {ref } 41}$; the values for $\mathbf{7}$ and $\mathbf{8}$ are from ref 49 .

${ }^{c}$ Data are from ${ }^{\text {ref } 39}$.

$d_{\text {Data are from }}$ ref 41 .

${ }^{e}$ ICE is based on a $48 \mathrm{~h}$ sample collection period.
} 
Table 2

Iron-Clearing Activity of Desferrithiocin Analogues When Administered Orally to Cebus apella Primates and the Partition Coefficients of the Compounds

Desferrithiocin Analogue $\quad$ Iron-Clearing Efficiency (\%) $)^{\boldsymbol{a}}$

(S)-4'-(HO)-DADFT, 1

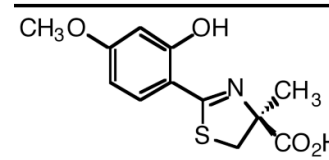

$24.4 \pm 10.8^{d}$

$-0.70$

(S)-4'-( $\left.\mathrm{CH}_{3} \mathrm{O}\right)$-DADFT, 2

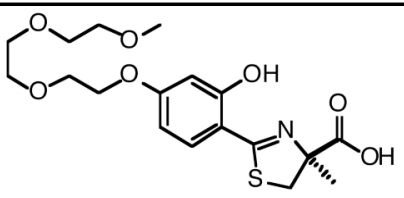

(S)-4'-(HO)-DADFT-PE, 3

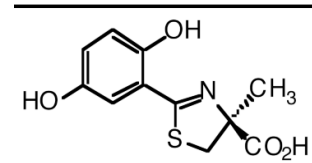

(S)-5'-(HO)-DADFT, 4

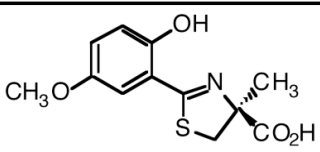

$(\mathrm{S})-5$ '- $\left(\mathrm{CH}_{3} \mathrm{O}\right)$-DADFT, 5

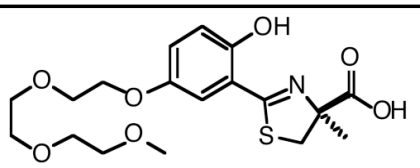

(S)-5'-(HO)-DADFT-PE, 6

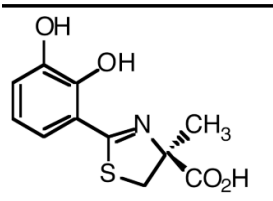

(S)-3'-(HO)-DADFT, 7

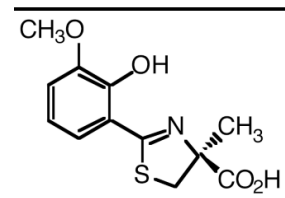

$22.5 \pm 7.1^{h}$

$[91 / 9]$

(S)-3'- $\left(\mathrm{CH}_{3} \mathrm{O}\right)$-DADFT, 8 
Desferrithiocin Analogue

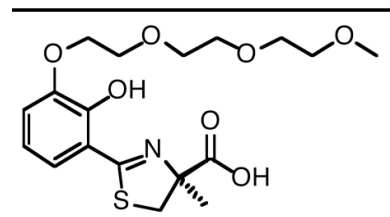

(S)-3'-(HO)-DADFT-PE, 9

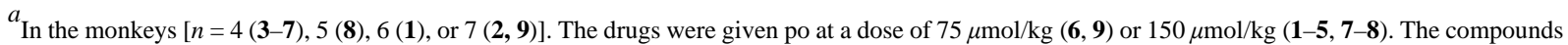
were solubilized in either distilled water $(\mathbf{3}), 40 \%$ Cremophor $(\mathbf{2}, \mathbf{7}, \mathbf{8})$, or were given as their monosodium salts, prepared by the addition of 1 equivalent of $\mathrm{NaOH}$ to a suspension of the free acid in distilled water $(\mathbf{1}, \mathbf{4 - 6}, \mathbf{9})$. The efficiency of each compound was calculated by averaging the iron output for 4 days before the administration of the drug, subtracting these numbers from the 2-day iron clearance after the administration of the drug, and then dividing by the theoretical output; the result is expressed as a percent. The relative percentages of the iron excreted in the stool and urine are in brackets.

$b$

${ }^{b}$ Data are expressed as the log of the fraction in the octanol layer (log $P_{\text {app }}$ ); measurements were done in TRIS buffer, pH 7.4, using a "shake flask"

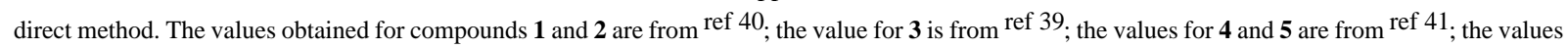
for $\mathbf{7}$ and $\mathbf{8}$ are from ref 49 .

${ }^{c}$ Data are from ref 48 .

$d_{\text {Data are from ref }} 40$.

$e_{\text {Data are from ref }}^{39}$.

$f_{\text {Data are from ref }} 41$.

$g_{\text {The dose was }} 75 \mu \mathrm{mol} / \mathrm{kg}$.

$h_{\text {Data are from ref }} 49$.
} 
Table 3

Iron-Clearing Efficiency Performance Ratios of Desferrithiocin Analogues in Primates versus Rodents

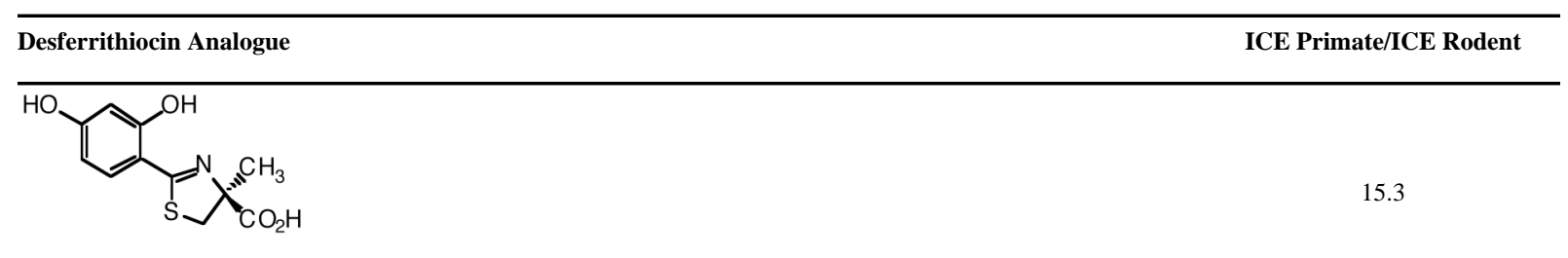

(S)-4'-(HO)-DADFT, 1

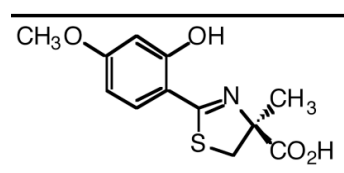

$(S)-4$ '- $\left(\mathrm{CH}_{3} \mathrm{O}\right)$-DADFT, 2

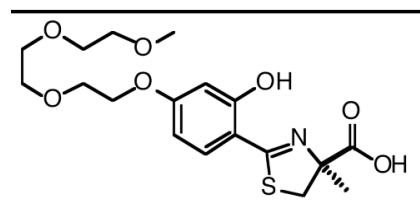

(S)-4'-(HO)-DADFT-PE, 3

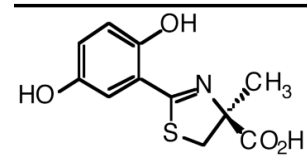

(S)-5'-(HO)-DADFT, 4

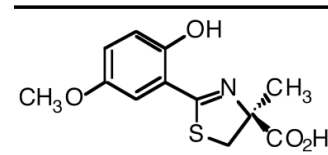

$(\mathrm{S})-5$ '- $\left(\mathrm{CH}_{3} \mathrm{O}\right)$-DADFT, 5

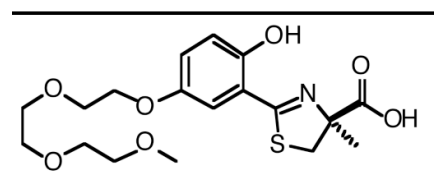

(S)-5'-(HO)-DADFT-PE, 6

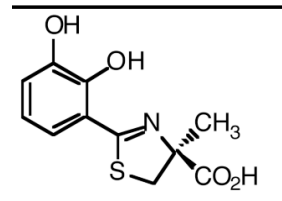

(S)-3'-(HO)-DADFT, 7

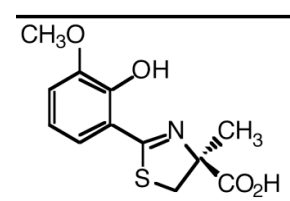

$(S)-3$ '- $\left(\mathrm{CH}_{3} \mathrm{O}\right)$-DADFT, 8 
Desferrithiocin Analogue

ICE Primate/ICE Rodent

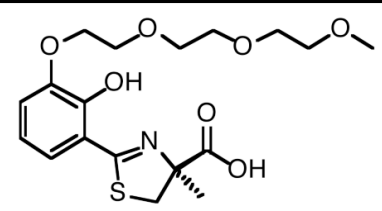

(S)-3'-(HO)-DADFT-PE, 9 
Table 4

Ligand-Albumin Binding in Rodents treated with Sodium Benzoate

\begin{tabular}{|c|c|c|c|c|}
\hline Experiment & Dose & Route & $\mathbf{N}$ & Iron-Clearing Efficiency $(\%)$ \\
\hline Sodium Benzoate & $250 \mathrm{mg} / \mathrm{kg} /$ dose & $\mathrm{sc}$ & 5 & baseline iron excretion \\
\hline$(S)-4^{\prime}-(\mathrm{HO})-\mathrm{DADFT}(\mathbf{1})$ & $300 \mu \mathrm{mol} / \mathrm{kg}$ & po & 8 & $1.1 \pm 0.8$ \\
\hline$(S)-4^{\prime}-(\mathrm{HO})-\mathrm{DADFT}(\mathbf{1})$ & $300 \mu \mathrm{mol} / \mathrm{kg}$ & po & & \\
\hline plus & & & 5 & $12.0 \pm 2.6^{a}$ \\
\hline Sodium Benzoate & $250 \mathrm{mg} / \mathrm{kg} / \mathrm{dose}$ & $\mathrm{sc}$ & & \\
\hline$(S)-4^{\prime}-(\mathrm{HO})-$ DADFT-PE (3) & $300 \mu \mathrm{mol} / \mathrm{kg}$ & po & 5 & $5.5 \pm 1.9$ \\
\hline (S)-4'-(HO)-DADFT-PE (3) & $300 \mu \mathrm{mol} / \mathrm{kg}$ & po & & \\
\hline plus & & & 4 & $8.8 \pm 2.4^{b}$ \\
\hline Sodium Benzoate & $250 \mathrm{mg} / \mathrm{kg} /$ dose & $\mathrm{sc}$ & & \\
\hline
\end{tabular}

Ligands 1 and $\mathbf{3}$ were administered po as their monosodium salts, prepared by the addition of 1 equivalent of $\mathrm{NaOH}$ to a suspension of the free acid in distilled water. Sodium benzoate was dissolved in distilled water and given sc at $250 \mathrm{mg} / \mathrm{kg} / \mathrm{dose} \times 6$ doses. The first dose of sodium benzoate was given $0.5 \mathrm{~h}$ prior to the chelators; additional doses were given hourly thereafter for the next $5 \mathrm{~h}$.

$a_{p}<0.001$ vs non-benzoate 1 treated animals.

${ }_{p}{ }_{p}<0.05$ vs non-benzoate 3 treated animals. 